\title{
Drought can favour the growth of small in relation to tall trees in mature stands of Norway spruce and European beech
}

\author{
Hans Pretzsch*, Gerhard Schütze and Peter Biber
}

\begin{abstract}
Background: Climate change triggered many studies showing that trends and events of environmental conditions can reduce but also accelerate growth at the stand and individual tree level. However, it is still rather unknown how climate change modifies the growth partitioning between the trees in forest stands.

Methods: Based on long-term girth-tape measurements in mature monospecific and mixed-species stands of Norway spruce (Picea abies (L.) Karst.) and European beech (Fagus sylvatica L.) we traced the effect of the severe droughts in 2003 and 2015 from the stand down to the tree level.

Results: Stand growth of Norway spruce decreased by about 30\% in the once-in-a-century drought 2015, while European beech was much more drought resistant. Water availability generally amplified size-asymmetric growth partitioning. Especially in case of Norway spruce water availability primarily fostered the growth of predominant trees, whereas drought favoured the growth of small trees at the expense of the predominant ones. We could not detect significant differences between mixed and monospecific stands in this regard.

Conclusions: The drought-induced reallocation of growth in favour of small trees in case of spruce may result from its isohydric character. We hypothesize that as small trees are shaded, they can benefit from the reduced water consumption of their sun-exposed taller neighbours. In case of beech, as an anisohydric species, tall trees suffer less and smaller trees benefit less under drought. The discussion elaborates the consequences of the water dependent growth allocation for forest monitoring, growth modelling, and silviculture.
\end{abstract}

Keywords: Growth partitioning, Drought, Competition symmetry, Climate change, Norway spruce, European beech

\section{Key message}

Water availability induced size-asymmetric growth partitioning. Drought favoured growth of small trees at the expense of predominant trees. Stand growth share of dominant trees changed with water availability.

\section{Background}

The social position of trees in even-aged stands results mainly from the share of contested resources they manage to acquire. It may depend on the availability of the various resources, to what extent predominant trees can benefit from their size and

\footnotetext{
* Correspondence: h.pretzsch@|rz.tum.de

Chair for Forest Growth and Yield Science, Center of Life and Food Sciences Weihenstephan, Technical University of Munich,

Hans-Carl-von-Carlowitz-Platz 2, 85354 Freising, Germany
}

privileged social position and how the resources and growth are distributed among the differently sized trees. Theory (Schwinning and Weiner 1998; Grote et al. 2016) and model studies (Hara 1993) consider a wide range from completely symmetric, to sizesymmetric, and strongly size-asymmetric interindividual resource and growth distribution patterns. The resource and growth distribution pattern in a given stand may depend on the environmental conditions, and especially on the prevailing resource limitation. Harsh environments with equal limitations of all resources may result in rather symmetric growth and resource distribution. Limitation by water and nutrient supply may cause a size-proportional, i.e. size symmetric competition. Limitation by light with ample supply of water and nutrients may result in a 
size-asymmetric competition and over-proportional growth of tall trees compared with small trees (Schwinning and Weiner 1998). Many empirical studies show that latter environment may enable dominant trees to pre-empt light and other resources and cause shading, growth reduction and eventually mortality of their smaller neighbours (Wichmann 2001; Pretzsch et al. 2012). The growth partitioning in mainly light-limited environments in temperate forests is rather well explored (Pretzsch and Biber 2010), represented in models (Biging and Dobbertin 1995), and applied for silvicultural prescriptions (Kramer 1988; Pretzsch and Zenner 2017). The growth partitioning under water limited conditions is rather far from being well explored and understood (Martínez-Vilalta et al. 2012; Grote et al. 2016). However, there are many scientific and practical reasons for deeper exploring it in this study.

Climate change may bring more frequently drought years or even turn many ecosystems from light limitation to water limitation (Bréda et al. 2006; del Río et al. 2017). As a consequence, the so far assumed size-asymmetric competition and over-proportional growth of tall trees compared with small trees may become more symmetric. The consequences would be far-reaching; they pertain to forest monitoring, modelling as well as silviculture.

Forest monitoring and inventory is often concentrated or even restricted to dominant trees and assumes their behaviour (e.g., growth reduction, vitality loss) to be representative for the growth of the whole stand. Suppose the pattern of inter-individual growth partitioning changes with environmental conditions in favour of small or tall trees, then scaling up from dominant trees to the behaviour of the stand growth may become flawed.

Change of growth allocation in favour of small or tall trees can modify the mode of mortality (i.e. the size distribution of the dying trees) and the stand structure. For thinning prescriptions it is important to know to what extent given social tree classes can be smoothly maintained or if they are at risk to become outcompeted. This is especially relevant when structural heterogeneity is among the silvicultural goals.

Modelling individual tree size growth and mortality is mostly based on competition indexes which quantify the local shading or stand density and assume that competition increases and growth decreases with shading and density (Pretzsch et al. 2002). This concept assumes that mainly light is pre-empted but implies that other resources are over-proportionally exploited by taller neighbours as well. Suppose primarily taller trees suffer drought stress and smaller trees would even benefit from their subdominant position. Under such circumstances conventional competition indices would at least temporarily misjudge the competitive status, growth, and mortality.
Finally, for goal-oriented silvicultural stand treatment under climate change it is important to know whether drought stress is equal for all trees in a stand or depending on size and social position. Suppose small trees benefit from shading and reduced water consumption of their tall neighbours; thinning from below would be unreasonable as it would eliminate the stabilizing effect of the small trees to whole stand growth.

Various studies analysed the drought reaction at different levels of organisation and found less growth reduction at the level of the whole stand compared to the collective of the dominant trees only (Martín-Benito et al. 2008; Jucker et al. 2014, 2016; Río et al. 2017a,b; Wellhausen et al. 2017). They suggest that trees of different social positions react differently and maybe small trees can partly compensate for the losses of tall trees and stabilise stand growth under drought. Wichmann (2001) provided evidence for this kind of behaviour on the basis of stem analyses in Sitka spruce. His finding that the relationship between tree size and size growth is steep in moist years and shallow in dry years (temporal variation) corroborates analogous findings on moist compared with dry sites (spatial variation) (Pretzsch 2010). However, previous studies mainly focussed on the tree level (effect on individuals). They hardly quantified the drought effect on the inter-individual growth partitioning and the share of different population fractions at total stand growth (effect on population structure).

This study is based on an 18-years-lasting monitoring of annual growth by permanently installed girth tapes in mature mono-specific and mixed-species stands of Norway spruce (Picea abies (L.) Karst.) and European beech (Fagus sylvatica L.). As the monitoring period covers both, extremely dry and moist years it provides a rather unique dataset for answering the following three questions:

Q1: How does stand volume growth depend on the water availability?

Q2: How does growth partitioning among trees of different sizes in a stand depend on water availability?

Q3: How does water availability modify the growth dominance and representativeness of tall compared to small trees in a stand?

\section{Methods}

\section{Study area and study period}

The study area Kranzberg Forest is located in Southern Germany, about $35 \mathrm{~km}$ in the Northeast of Munich (longitude: $11^{\circ} 39^{\prime} 42^{\prime \prime} \mathrm{E}$, latitude: $48^{\circ} 25^{\prime} 12^{\prime \prime} \mathrm{N}$, altitude $490 \mathrm{~m}$ a.s.l). The average annual precipitation amounts to $750-800 \mathrm{~mm}$ per year and to $460-500 \mathrm{~mm}$ during the growing season (May-September), both observed in the period 1971-2000. For the same period, the average air temperature is $7.8{ }^{\circ} \mathrm{C}$ (annual mean) and $13.8{ }^{\circ} \mathrm{C}$ 
(May-September). The soil is a luvisol originating from loess over Tertiary sediments and provides high nutrient and water supply (Pretzsch et al. 1998; Göttlein et al. 2012). Depending on soil depth the water holding capacity for plant available water ranged between 115 and $255 \mathrm{~mm}$, while soil $\mathrm{pH}_{\mathrm{H}_{2} \mathrm{O}}$ varied between 4.1 and 5.1.

\section{Field measurements}

The 0.5 ha Kranzberg study site was established in 1992 in a 41-61 years old Norway spruce and European beech stand. For the purpose of this study, the Kranzberg site was subdivided into three plots; one plot represents both species growing in mixture, while the others represent monospecific stands of spruce and beech, respectively. The size of the pure Norway spruce and European beech plots was 0.07 and 0.03 ha, respectively, and of the mixed-species plot 0.08 ha.

We measured the stem diameters at breast height $(1.3 \mathrm{~m})$, tree heights, and heights to the crown base in 1994, 1999, 2005, and 2012 with a girth tape and a Vertex height measurement device. In addition, annual diameter growth at breast height was recorded since 1998 with permanent diameter tapes which were equipped with Vernier scales for circumferential recording with $1 \mathrm{~mm}$ resolution (UMS, Germany). For further details of measurement and stand characteristics see (Pretzsch et al. 1998, 2016; Häberle et al. 2012; Goisser et al. 2016).

In 2016 the tree age within the mixed stand plot was assessed for verification purposes and confirmed with $65 \pm 2$ years for spruce and $85 \pm 4$ years for beech. The stand structure has not been disturbed by silvicultural interference since the establishment of the experimental site. Thus, the growth partitioning between the trees represents the natural dynamics under self-thinning conditions. The results of this study can therefore be considered free of confounding effects due to interventions by forest management.

Table 1 shows that Norway spruce and European beech have similar sizes in the mono-specific and mixed stands. Although twenty years older than spruce, European beech is lacking behind in size growth because of its speciesspecific lower and later-culminating course of growth. The range between minimum and maximum values is much lower for Norway spruce than for European beech. While the mean size of beech is generally lower than that of spruce, their maximum values are rather similar. So, the beech population is much more heterogeneous in size including very small but also rather tall trees, whereas Norway spruce shows a much narrower size range.

The number of girth tapes mounted in 1998 in the mono-specific stands was $n=56$ for Norway spruce and $n=34$ for European beech. The sample size on the mixed-species plots was $n=30$ and $n=45$ for Norway
Table 1 Sample sizes and tree dimensions in 2016 (last survey) as well as mean annual tree volume growth in 1998-2016 for Norway spruce and European beech in mono-specific and mixed-species stands used for this study

\begin{tabular}{|c|c|c|c|c|c|}
\hline & $n_{2016}$ & $d(\mathrm{~cm})$ & $h(\mathrm{~m})$ & $v\left(m^{3}\right)$ & $i V_{1998-2016}\left(\mathrm{dm}^{3} \cdot \mathrm{yr}^{-1}\right)$ \\
\hline \multicolumn{6}{|l|}{ monospecific stands } \\
\hline Norway spruce & 43 & & & & \\
\hline mean & & 34.8 & 32.2 & 1.54 & 32.4 \\
\hline $\min$ & & 21.5 & 27.7 & 0.50 & 0.80 \\
\hline $\max$ & & 51.0 & 35.3 & 3.23 & 95.0 \\
\hline European beech & 28 & & & & \\
\hline mean & & 26.0 & 27.7 & 0.87 & 18.8 \\
\hline $\min$ & & 11.3 & 20.0 & 0.09 & 0.40 \\
\hline $\max$ & & 48.1 & 32.0 & 3.07 & 77.2 \\
\hline \multicolumn{6}{|l|}{ mixed-species stand } \\
\hline Norway spruce & 19 & & & & \\
\hline mean & & 35.8 & 32.4 & 1.62 & 30.1 \\
\hline $\min$ & & 18.9 & 26.1 & 0.36 & 0.40 \\
\hline $\max$ & & 48.0 & 34.9 & 2.86 & 69.0 \\
\hline European beech & 35 & & & & \\
\hline mean & & 28.4 & 28.5 & 1.05 & 17.1 \\
\hline $\min$ & & 15.4 & 23.6 & 0.20 & 0.30 \\
\hline $\max$ & & 47.9 & 32.0 & 3.05 & 91.7 \\
\hline total & 54 & & & & \\
\hline mean & & 31.0 & 29.9 & 1.25 & 23.2 \\
\hline $\min$ & & 15.4 & 23.6 & 0.20 & 0.30 \\
\hline $\max$ & & 48.0 & 34.9 & 3.05 & 91.7 \\
\hline
\end{tabular}

Sample size in $2016\left(n_{2016}\right)$, mean, minimum, and maximum values of stem diameter $(d)$ at breast height, tree height $(h)$ and tree volume $(v)$, mean annual volume growth in the period 1998-2016 (iv $1998-2016)$

spruce and European beech, respectively. As some trees died in the period 1998-2016 the sample sizes were slightly lower in 2016 (see Table 1).

\section{Annual temperature, precipitation, and Martonne index in the study period}

For characterizing the water supply for each year we calculated the de Martonne index $M$ (de Martonne 1926)

$$
M=\frac{P}{T+10}
$$

based on the precipitation $P$ (in $\mathrm{mm}$ ) and mean temperature $T$ (in ${ }^{\circ} \mathrm{C}$ ) of the whole year (resulting in an annual Martonne index, $M_{\mathrm{y}}$ ). The same was done using precipitation and mean temperature for the growing season only (defined as 1 May - 30 September), which resulted in a growing-season Martonne index $M_{\mathrm{gs}}$. Because of its minimal data requirement and at the same time high explanative strength, the Martonne index has 
been widely used in modern studies to describe the drought conditions or aridity in a given region (Rötzer et al. 2012; Pretzsch et al. 2013; Quan et al. 2013). The higher the $M$ index, the better the water supply for plant growth. In the period from 1998 to $2016 M_{\mathrm{gs}}$ varied between $11.5-24.4 \mathrm{~mm} \cdot{ }^{\circ} \mathrm{C}^{-1}$ during the period AprilSeptember and $M_{\mathrm{y}}$ between $29.7-64.5 \mathrm{~mm} \cdot{ }^{\circ} \mathrm{C}^{-1}$ at the Kranzberg site, indicating a broad variation of water availability (Fig. 1). Hereby, the years 2001-2002 and 2005-2013 were rather moist years while 2003 and 2015 were extremely dry.

The meteorological data come from the nearby forest weather station Freising, which is part of the Bavarian Environmental Monitoring System (LWF 2017).

\section{Applied dendrometrical methods}

\section{Calculation of tree height, basal area, and volume growth}

For hypothesis testing we calculated the annual stem volume growth at the three levels individual tree, species, and total stand. We based the calculation on the annual stem diameter records at $1.30 \mathrm{~m}$ height (permanent dendrometers read off each year in October) in the years 1998-2016 and the available height measurements in the years 1994, 1999, 2005, 2012, and 2014. The sample size ( $n_{\text {sp }}$ and $\left.n_{\text {be }}\right)$ of the height measurements were for spruce and beech $n_{\mathrm{sp}}=42$ and $n_{\mathrm{be}}=41$ in 1994, $n_{\mathrm{sp}}=102$ and $n_{\mathrm{be}}=64$ in 1999, $n_{\mathrm{sp}}=237$ and $n_{\mathrm{be}}=112$ in 2005, $n_{\mathrm{sp}}=111$ and $n_{\mathrm{be}}=62$ in 2012, $n_{\mathrm{sp}}=39$ and $n_{\mathrm{be}}=41$ in 2014, and $n_{\mathrm{sp}}=531$ and $n_{\mathrm{be}}=320$ in total.

For all trees with recorded height and diameter values we fitted the following Michailov-based diameter-time tree height model (see Biber 2013) separately for both species with nonlinear regression: $h=\left(a_{0}+a_{1}\right.$ year $)$ $e^{-\frac{b_{0}+b_{1} \text { year }}{d}}$. This yielded parameter estimates for $a_{0}, a_{1}, b_{0}$, $b_{1}$ which allow to estimate the tree height $h$ corresponding to a given stem diameter $d$ in a given calendar year. Subsequently, we used this model for estimating realistic height values for each tree from 1998 to 2016. Using the individual trees' diameters $d_{n}$ and corresponding height estimates $h_{n}$ in year $n(n=1998,1999, \ldots, 2016)$, and their form factors $f_{n}$ (Franz et al. 1973), which depend from tree species and individual $d_{n}$ and $h_{n}$, we were able to calculate each tree's volume $v_{n}=d_{n}^{2} \frac{\pi}{4} h_{n} f_{n}$. Accordingly, the tree-specific annual volume increment $i v_{n}$ between the subsequent years could be easily obtained by subtracting volume values: $i v_{n}=\left(v_{n}-v_{n-1}\right)$. As the applied form factors depend on both, current stem diameter and current tree height, stem shape changes are taken into account by this procedure.

All stand characteristics such as mean diameters and heights for the total stand and dominant trees, stand basal area $(B A)$, or standing volume stock per hectare $(v)$ and stand volume growth (iv) for the surveys in 19982016 were evaluated following the DESER-Norm from 1993 (Johann 1993; Pretzsch 2009).

For the subsequent evaluation the annual volume growth of all individual trees in the mono-specific and mixed species stands was most relevant. In addition we calculated the volume growth per hectare $\left(\mathrm{m}^{3} \cdot \mathrm{ha}^{-1} \cdot \mathrm{yr}^{-1}\right)$ by dividing the sum of the tree volume growth of all trees by the actual plot area in ha.

Stand productivity of monospecific and mixed species stands The comparison of the effect of water availability on the productivity of mixed versus monospecific stands was

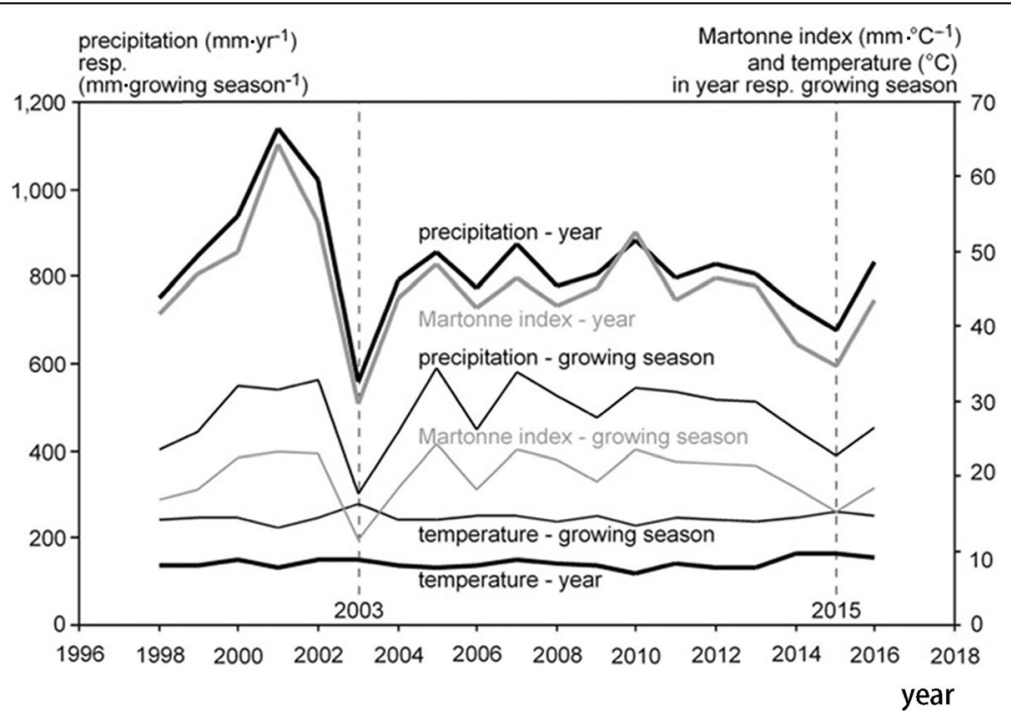

Fig. 1 Course of the precipitation, mean temperature, and Martonne index from 1998 to 2016 in the whole year and in the growing season (May-September) for the Kranzberg Forest experimental site. In the years 2003 and 2015 water availability was pronouncedly low 
based on the course of annual stem volume productivity (abbrev. 'iv': increment of volume), of Norway spruce and European beech in the monospecific stands $\left(i v_{\text {N.sp. }}\right.$, $i v_{\text {E.be. }}$ ), the species specific productivity of spruce and beech in the mixed stand $\left(i v_{\text {N.sp., }}\right.$ (E.be.) $i v\left(v_{\text {N.sp.), E.be. }}\right)$ and the mixed stand as a whole $\left(i v_{\text {N.sp., E.be. }}\right)$ (see Table 2$)$.

As can be taken from Table 2, European beech is about 20 years older in both mono-specific and mixed species stands, i.e., it had been established ahead of Norway spruce by advance planting. Mean and dominant tree sizes are rather similar on the monospecific and mixed-species plots. By dominant heights of more than $33 \mathrm{~m}$ at the age of 62 and 82 both species indicate top growing conditions, i.e., site indexes of $\mathrm{O} 40$ according to the yield table of (Assmann and Franz 1963) for Norway spruce (mean height of $37.4 \mathrm{~m}$ at age 100) and I. site class according to (Schober 1975) for European beech (mean height of $31.4 \mathrm{~m}$ at age 100).

\section{Quantifying the relationship between tree growth (iv) and tree volume ( $v$ )}

According to Prodan (1965, p 474-476) the interindividual relationship between tree volume growth $(i v)$ within a year (or an otherwise defined growth period) and tree volume $(v)$, at the beginning of the growth period can be described by a simple linear model. Fitting such a linear model $i v=a+b v$ with parameters $a$ and $b$ through the $i v-v$ data by OLS-regression yielded the intercept $a$ and the slope $b$. The procedure was applied separately for each year from 1998 to 2016 and for Norway spruce and European beech in mono-specific and mixed-species stands separately. The resulting calendar year specific values for $a$ and $b$ (Additional file 1: Tables S1-S6) were used for analyzing whether and how the annual weather conditions and the species mixing modify the $i v-v$ relationship.

In a preliminary analysis we also fitted the secondorder polynomial equation $i v=a+b v+c v^{2}$ in order to reveal any nonlinear trends in the annual inter- individual relationship between volume growth and tree volume (plausibility verified by visual assessment of the fitted polynomials). As only in 24 of our 76 regressions the quadratic element, in terms of the regression parameter $c$ was significantly different from zero, we based the analyses on the linear model shown above.

\section{Calculating the growth dominance coefficient (GDC)}

As a prerequisite for analyzing the dependency of the growth dominance of tall versus small trees on the water availability (Q3) we calculated the growth dominance coefficient, GDC (Binkley et al. 2006; Pretzsch et al. 2017). The concept of the growth dominance can be visualized by the cumulative distribution of tree growth over stem volume (Fig. 2). For this purpose the trees of the stand are arranged from the smallest to the largest volume; the $\mathrm{cu}-$ mulative volume of the trees is registered on the abscissa, and the cumulative volume growth is noted along the ordinate. The resulting curves illustrate how much smaller trees contribute to the total stand growth compared with taller trees: Curve 1 in Fig. 2 indicates a growth dominance of tall trees, curve 3 a growth dominance of small trees, and curve 2 , following the bisector line, indicates that all trees contribute to stand volume growth proportionally to their volume. The $G D C$ is a numerical representation of this concept and thus reflects, whether the efficiency of tree volume investment is the same for trees of all sizes, or how it changes with tree size (Binkley et al. 2006). Technically, the $G D C\left(G D C=G C_{i v}-G C_{v}\right)$ is the difference of the Gini coefficient for cumulative growth $\left(G C_{i v}\right)$ minus the Gini coefficient for cumulative volume $\left(G C_{v}\right)$. These Gini coefficients, $G C_{i v}$ and $G C_{v}$, were calculated as

$$
G C=\frac{\sum_{i=1}^{n} \sum_{j=1}^{n}\left|x_{i}-x_{j}\right|}{2 n(n-1) \bar{x}}
$$

(see De Camino 1976; Kramer 1988). The variables $x_{i}$ and $x_{j}$ denote size or growth (or other tree

Table 2 Stand data of the monospecific and mixed species plots of Norway spruce and European beech for the last survey in 2016 and mean stand volume growth for the whole survey period from 1998 to 2016

\begin{tabular}{|c|c|c|c|c|c|c|c|c|c|}
\hline & $\begin{array}{l}\text { age }_{2016} \\
\text { (years) }\end{array}$ & $\begin{array}{l}d_{\mathrm{a}} \\
(\mathrm{cm})\end{array}$ & $\begin{array}{l}d_{o} \\
(\mathrm{~cm})\end{array}$ & $\begin{array}{l}h_{\mathrm{a}} \\
(\mathrm{m})\end{array}$ & $\begin{array}{l}h_{\circ} \\
(\mathrm{m})\end{array}$ & $\begin{array}{l}n \\
\left(\mathrm{ha}^{-1}\right)\end{array}$ & $\begin{array}{l}B A \\
\left(\mathrm{~m}^{2} \cdot h a^{-1}\right)\end{array}$ & $\begin{array}{l}v \\
\left(\mathrm{~m}^{3} \cdot h a^{-1}\right)\end{array}$ & $\begin{array}{l}\text { iv } 1998-2016 \\
\left(\mathrm{~m}^{3} \cdot \mathrm{ha}^{-1} \cdot \mathrm{yr}^{-1}\right)\end{array}$ \\
\hline \multicolumn{10}{|l|}{ mono-specific stands } \\
\hline Norway spruce & 65 & 35.5 & 44.9 & 32.7 & 34.3 & 639 & 60.1 & 981 & 26.3 \\
\hline European beech & 85 & 27.2 & 41.4 & 29.2 & 33.0 & 926 & 54.0 & 802 & 19.4 \\
\hline \multicolumn{10}{|l|}{ mixed-species stand } \\
\hline Norway spruce & 65 & 36.4 & 41.7 & 32.9 & 33.8 & 237 & 24.7 & 315 & 10.4 \\
\hline European beech & 85 & 29.6 & 41.9 & 30.0 & 33.1 & 437 & 30.1 & 383 & 9.2 \\
\hline total & - & - & - & - & - & 674 & 54.8 & 698 & 19.6 \\
\hline
\end{tabular}

Stand age in 2016 (age 2016 ), quadratic mean diameter $\left(d_{\mathrm{q}}\right)$, mean diameter of the 100 tallest trees $\left(d_{\mathrm{o}}\right)$, height of the $d_{\mathrm{q}}$ tree $\left(h_{\mathrm{q}}\right)$, height of the $d_{\mathrm{o}}$ tree $\left(h_{\mathrm{o}}\right)$, tree number per hectare $(n)$, stand basal area per hectare $(B A)$, standing stem volume per hectare $(v)$, mean annual stand volume growth in the period 1998-2016 (iv $1998-2016)$ 


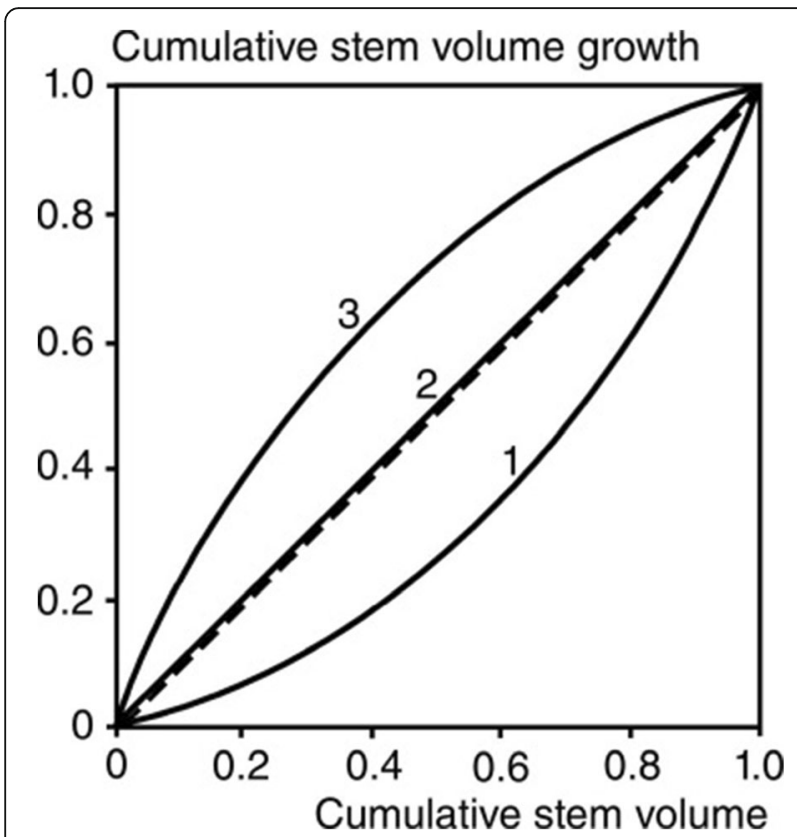

Fig. 2 Schematic representation of the cumulative distribution of stem volume growth (ordinate) over stem volume (abscissa) for forest stands with different competitive status of small compared with tall trees. Curve 1 indicates a growth dominance of tall trees, curve 3 a growth dominance of small trees, and curve 2 indicates that all trees contribute to stand volume growth proportionally to their volume. Curves 1, 2, and 3 result in $G D C=0.17,0$ and -0.12

characteristics) for the $i$ 'th and the $j$ 'th tree in a stand with $n$ trees. If the curve of the cumulative distribution of tree growth over stem volume follows the bisectoral line the $G D C$ equals zero. $G D C$ is less than zero, if it runs above the bisectoral line, and if the curve lies below the bisector line, the $G D C$ is greater than zero (see curves 3 and 1, respectively, in Fig. 2).

Any changes of the GDC depending on the Martonne index indicate that trees of different size react differently on the variation of water supply so that the growth partitioning pattern among the population changes. If water supply would affect the growth of all trees in a population in the same way, GDC would remain constant as only the absolute growth rate but not its partitioning among the trees changed. However, an increase of GDC would mean an increasing growth of the tall trees in relation to their share of the stand volume, i.e., the growth efficiency (growth/standing stock) of the tall trees increases. In contrast, a decreasing $G D C$ would indicate an increasing growth efficiency of the small trees in relation to their tall neighbours.

\section{Growth share and drought resistance of different population strata}

Despite the $G D C$ is common in ecology but rather abstract, we calculated two additional measures for quantifying the effect of water availability on the growth dominance and representativeness of tall compared to small trees.

First, we isolated the collectives of the $10 \%$ smallest and the $10 \%$ tallest trees in our data based on the stem volume. For both groups and each year in the period 1998-2016 we calculated their shares of the total stand productivity. If drought would affect both collectives in the same way, the course of the shares over the years should be synchronous; i.e., low and high shares should occur simultaneously for both groups, or the shares should not considerably change at all.

Second, we calculated the drought resistance, $R t$, for the three strata 1) dominant trees (100 tallest trees per hectare), 2) subdominant (100 smallest), and 3) all trees according to the concept by Lloret et al. (2011). Rt is the ratio between the relative volume growth in a drought year (2003 or 2015) and the mean volume growth in the 3 years before the drought, i.e., in the pre-drought periods 2000-2002 and 2012-2014, respectively. $R t$ reflects the extent to which the tree growth of the different size strata decreased due to drought stress compared to the 'normal' level of growth. In case of equal drought reactions of all size strata, there would be no significant differences between their $R t$ values.

\section{Statistical methods applied for answering the questions Q1-Q3}

The data material prepared as described above was subsequently used for statistical scrutiny of the three research questions of this study.

\section{Q1: How does stand volume growth depend on the water availability?}

For answering how water stress affects stand growth of Norway spruce compared to European beech in monospecific and mixed-species stands (Q1) we used the annual stand volume growth records $i v$ and the Martonne index for the growing season, $M_{\mathrm{gs}}$ as basic variables. We focused on $M_{\mathrm{gs}}$, because preliminary analyses suggested this variable as a better predictor than its whole-year counterpart $M_{\mathrm{y}}$. After visual data inspection we deemed the simple linear model $i v=a+b M_{\mathrm{gs}}$ as sufficient for describing the relation between stand volume increment and the Martonne index. In order to be able to contrast different tree strata (e.g. Norway spruce in monospecific stands against European beech in monospecific stands) inside this concept, we formulated the following OLS regression model

$$
i v=a_{0}+a_{1} c t g+b_{0} M_{\mathrm{gs}}+b_{1} M_{\mathrm{gs}} c t g+\varepsilon
$$

by introducing the predictor $c t g$, which is a two-level categorical variable used for the required comparisons 
(details below). Given the above-mentioned general Model $i v=a+b M_{\mathrm{gs}}$, the parameters $a_{0}$, and $a_{1}$ are the components of its intercept $a$ while $b_{0}$ and $b_{1}$ form together the slope $b\left(a=a_{0}+a_{1} c t g, b=b_{0}+b_{1} c t g\right)$. Assume, the variable $\mathrm{ctg}$ is used for contrasting the category "Norway spruce in monospecific stands" $(\operatorname{ctg}=0)$ against "European beech in monospecific stands" $(\operatorname{ctg}=1)$. In this case, $a_{0}$ and $b_{0}$ represent the intercept and the slope for spruce, while $a_{0}+a_{1}$ and $b_{0}+b_{1}$ are the intercept and the slope for beech. Only if $a_{1}$ or $b_{1}$ differ significantly from 0 , the assumption that the intercept or the slope is different for both species is justifiable. If this was the case, either for $a_{1}, b_{1}$ or for both, we concluded that the linear relationships for the two categories under comparison were different.

In total, we made six two-category comparisons with corresponding coding of the variable $c t g$ (Table 3). These comparisons were 1) beech in monospecific stands vs. spruce in monospecific stands, 2) beech in mixed stands vs. spruce in mixed stands, 3) beech in mixed stands vs. mixed stands in total, 4) spruce in mixed stands vs. mixed stands in total, 5) spruce in mixed stands vs. spruce in monospecific stands, and 6) beech in mixed stands vs. beech in monospecific stands. Before feeding them in this analysis, all volume increments (including those of single species in mixed stands) were extrapolated to an area of 1 ha in order to make them comparable.

Q2: How does growth partitioning among trees of different sizes in a stand depend on water availability?

For analysing how growth response to drought depends on the size of a tree in a stand (Q2) we first fitted the annual $i v-v$ relationships by OLS regression which yielded the annual intercept $a$ and slope $b$ for all considered groups (see section 'Quantifying the relationship

Table 3 Comparisons made with the regression models after Eq. 1 and corresponding coding of the variable ctg

\begin{tabular}{|c|c|c|c|}
\hline & Category 1 & vs. & Category 2 \\
\hline Comparison 1 & Spruce monospecific & & Beech monospecific \\
\hline $\operatorname{ctg}$ & 0 & & 1 \\
\hline Comparison 2 & Spruce in mixture & & Beech in mixture \\
\hline $\operatorname{ctg}$ & 0 & & 1 \\
\hline Comparison 3 & Total mixed stand & & Beech in mixture \\
\hline $\operatorname{ctg}$ & 0 & & 1 \\
\hline Comparison 4 & Total mixed stand & & Spruce in mixture \\
\hline $\operatorname{ctg}$ & 0 & & 1 \\
\hline Comparison 5 & Spruce monospecifc & & Spruce in mixture \\
\hline $\operatorname{ctg}$ & 0 & & 1 \\
\hline Comparison 6 & Beech monospecific & & Beech in mixture \\
\hline $\mathrm{ctg}$ & 0 & & 1 \\
\hline
\end{tabular}

between tree growth, $i v$, and tree volume, $v$ and intercepts and slopes presented in Additional file 1: Tables S1-S6). Then the intercepts and slopes of the annual $i v-v$ relationships at the individual tree level were set in relation to the Martonne index, $M_{\mathrm{ggs}}$. For this purpose we applied the two different OLS regression models:

$$
\begin{aligned}
& \text { intercept }=a_{0}+a_{1} c t g+b_{0} M_{\mathrm{gs}}+b_{1} M_{\mathrm{gs}} c t g+\varepsilon \\
& \text { slope }=a_{0}+a_{1} c t g+b_{0} M_{\mathrm{gs}}+b_{1} M_{\mathrm{gs}} c t g+\varepsilon
\end{aligned}
$$

In these models the dependent variables "intercept" and "slope" are the intercepts and slopes previously obtained by fitting the annual $i v-v$ relationships with OLS regression models for all categories of interest. While the parameters and variables are the same as explained along with Eq. 1, the comparisons made and consequently the coding of the variable $\operatorname{ctg}$ used for Q2 are different (Table 4). The comparisons were 1) spruce altogether (in mixed and monospecific stands) vs. beech altogether, 2) spruce in monospecific vs. spruce in mixed stands, 3) beech in monospecific vs. beech in mixed stands. In the same way as for Q1, significances of the parameters $a_{1}$ and $b_{1}$ were taken as criteria for determining differences between the regression lines of two categories coded with the variable $c t g$.

\section{Q3: How does the water availability modify the growth dominance and representativeness of tall compared to small trees in a stand?}

For scrutiny whether there are effects of water availability on the growth dominance of trees $(\mathrm{Q} 3)$ we related both variables $G D C$ and $M_{\mathrm{gs}}$ by the model

$$
G D C=a_{0}+a_{1} c t g+b_{0} M_{\mathrm{gs}}+b_{1} M_{\mathrm{gs}} c t g+\varepsilon
$$

with the analogous meanings of all variables and parameters as in Eqs. 1, 2a and 2b. The same categories were compared as for Q2 (Table 4).

Based on autocorrelation function plots, the residuals of all models shown above (Eqs. 1, 2a, 2b, 3) were visually assessed for serial autocorrelation which was found to be negligible. All statistical evaluations were conducted with R 3.3.2 (R Core Team 2016) and MS Excel.

\section{Results}

Q1: Stand volume growth depending on water availability Figure $3 \mathrm{a}$ and $\mathrm{b}$ show the course of stand volume growth in the period 1998-2016 for (a) the monospecific stands of Norway spruce and European beech and (b) for the mixed stand in total and for both species' contributions to the mixed stand's growth. Both figures illustrate that the growth of Norway spruce oscillates stronger than European beech with more pronounced growth 
Table 4 Comparisons made with the regression models shown in Eqs. 2a, 2b, 3 and corresponding coding of the variable ctg

\begin{tabular}{|c|c|c|c|}
\hline & Category 1 & vs. & Category 2 \\
\hline Comparison 1 & Spruce mixed and monospecific & & Beech mixed and monospecific \\
\hline $\operatorname{ctg}$ & 0 & & 1 \\
\hline Comparison 2 & Spruce in monospecific & & Spruce in mixture \\
\hline $\operatorname{ctg}$ & 0 & & 1 \\
\hline Comparison 3 & Beech monospecific & & Beech in mixture \\
\hline $\operatorname{ctg}$ & 0 & & 1 \\
\hline
\end{tabular}

reductions in dry years. The low growth years 2003 and 2015 are indicated in the Figure by broken vertical lines.

Figures $3 \mathrm{c}$ and $\mathrm{d}$ show the annual stand volume growth in dependence on the Martonne index. It is shown for the mono-specific stands of Norway spruce and European beech (c) and for the total and the species stand volume growth in the mixed-species stand (d); here, both species' volume growth was converted into ha-related values by dividing it by their area shares in the mixed stand. The obvious differences in the relationship between water availability and growth were corroborated by the statistical analyses based on model Eq. 1,
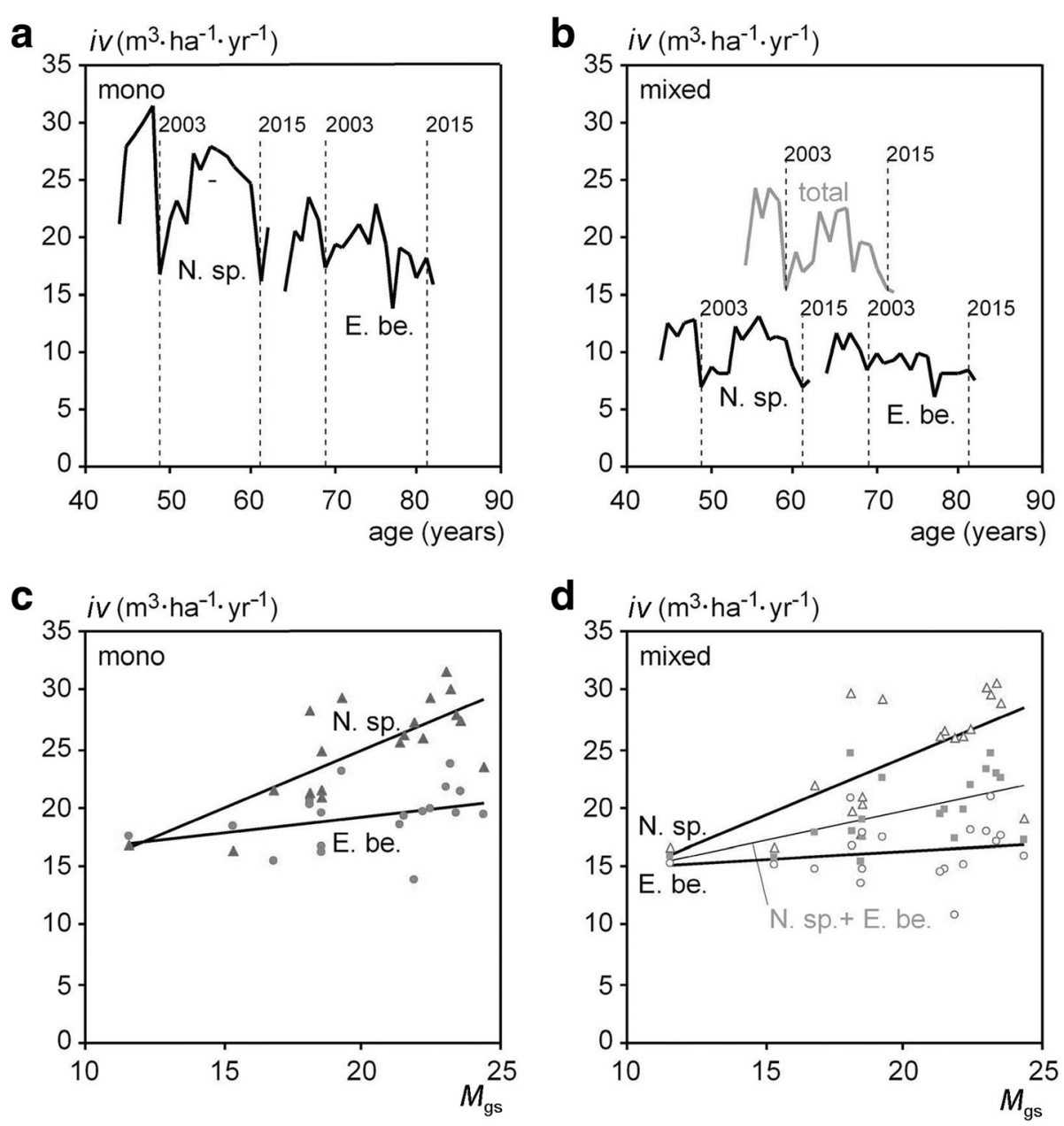

Fig. 3 Stand volume growth in the monospecific and mixed-species stands of Norway spruce and European beech of the Kranzberg forest experiment from 1998 to 2016 shown in relation to stand age and in relation to water availability (de Martonne index for the growing season, $M_{\mathrm{gs}}$ ). Upper panel: Annual stand volume growth of Norway spruce and European beech for (a) the mono-specific stands and (b) total and species stand volume growth in the mixed-species stand. Lower panel: Annual stand volume growth dependent on the Martonne index shown for (c) the mono-specific stands of Norway spruce and European beech and (d) the total and species specific stand volume growth in the mixed-species stands. Note that in (d) the species specific growth values have been converted into ha-values by dividing them by their area share in the mixed stand 
as presented in the method section. This analysis resulted in the regression lines included in Fig. $3 \mathrm{c}$ and d. The statistical analysis could be based on the absolute stand growth rates as there were no significant differences in the age trend between the considered groups. The model fit results are shown in detail in Table 5.

Table 5 , in its upper part, reflects by the parameter $b_{0}$ of model Eq. 1 that the growth rates always increase with increasing Martonne index values; in most of the cases the increase is significant. As explained in the methods section, the parameter for $a_{0}, a_{1}, b_{0}, b_{1}$ are the components of the slope $b$ and intercept $a$ of a simple linear relationship between volume growth and the Martonne index. The values of these slopes and intercepts as calculated from the parameter estimates in the upper part of Table 5 are presented in the lower part the table. These slopes $b$ range between 0.128 and 0.992 . The increase of growth with increasing water availability (equivalent with the decrease of growth with decreasing water availability), is strongest in case of Norway spruce in pure stands $(b=0.992)$ and just slightly lower for spruce in mixed stands $(b=0.970)$. Stand growth of beech in monoculture $(b=0.263)$ and mixture $(b=0$. $128)$ is less water-dependent. The mixed stand as a whole lies in between $(b=0.490)$. In monospecific as well as in mixed stands, the slope $b$ of beech is significantly lower compared to spruce.

This means that the sensitivity to drought differs significantly between Norway spruce and European beech. However, Norway spruce and European beech do not differ in their behaviour in mixed compared with monospecific stands. These results are visualized in Fig. 3c and $\mathrm{d}$. The relationships of water availability and stand growth are steeper for spruce than for beech. Both species show a similar species specific behaviour in monospecific and mixed-species stands. The relationship between the relative growth and the Martonne index $M_{\mathrm{gs}}$ of the mixed-species stand in total lies between the two speciesspecific lines of Norway spruce and European beech (see Fig. 3d, grey line). This underlines, that the behaviour of the mixed stand is just an additive effect.

\section{Q2: Growth partitioning among trees of different sizes depending on water availability}

For illustrating the $i v-v$ relationships for Norway spruce compared with European beech and the dependency of these relationships on water availability we selected the 2 years 2001 and 2007 with the highest $M_{\mathrm{gs}}$ index $\left(M_{\mathrm{gs}}=23.2,23.6\right)$ and 2003 and 2015 with the lowest $M_{\mathrm{gs}}$ index $\left(M_{\mathrm{gs}}=11.5,15.3\right)$ within the period 1998-2016. Figure 4a and b, show that the linear $i v-v$ relationships for Norway spruce lie generally higher than for European beech. Furthermore, the figure shows for both species that these relationships are steeper in the moist years $(2001,2007)$ compared with the dry years $(2003,2015)$. This means that in moist years tall trees grow over-proportionally compared with small trees and competition is more sizeasymmetric. In dry years, in contrast, the advantage of tall trees decreases and competition becomes more size-symmetric.

Table 5 Upper part: Results of the pairwise comparisons by fitting Eq. 1 (corresponding to Q1)

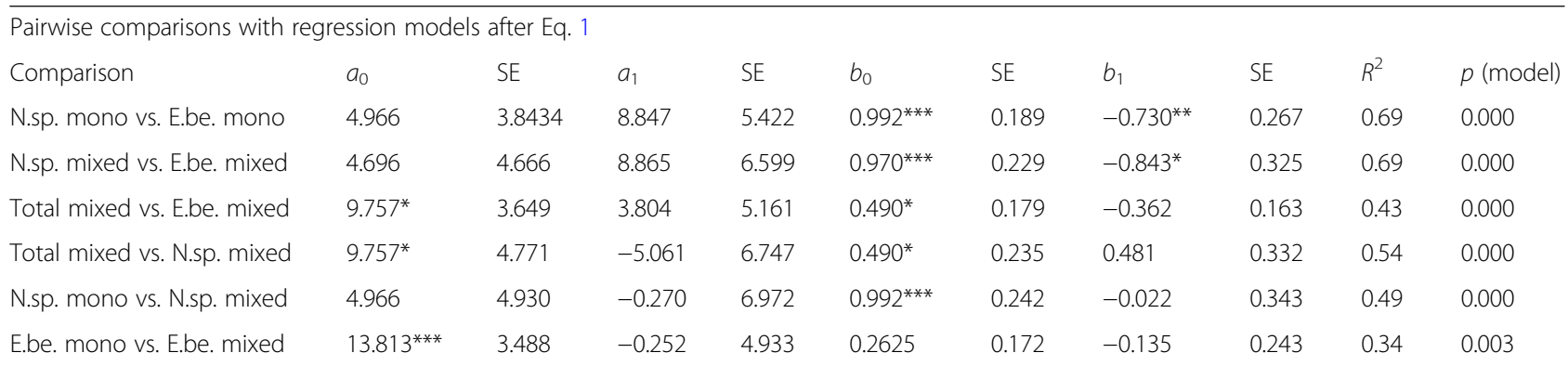

Resulting linear models $i v=a+b M_{\mathrm{gs}}$

$\begin{array}{lll}\text { Category } & a & b \\ \text { N.sp. mono } & 4.966 & 0.992 \\ \text { E.be. mono } & 13.813 & 0.263 \\ \text { N.sp. mixed } & 4.696 & 0.970 \\ \text { E.be. mixed } & 13.561 & 0.128 \\ \text { Total mixed } & 9.757 & 0.490\end{array}$

Lower part: Linear models for the different species/stand categories resulting from combining the corresponding parameter estimates from the upper part. If two categories have the same letter under 'diff', their linear models differ significantly due to the significances shown in the upper part of the table. Not all possible combinations of categories were tested against each other; see column 'comparison' for the performed tests. N.sp, Norway spruce, E.be European beech. Significant differences of the parameters between the groups are indicated by the levels of significance $\left({ }^{*} p<0.05\right.$, $\left.{ }^{* *} p<0.01,{ }^{* * *} p<0.001\right)$ 

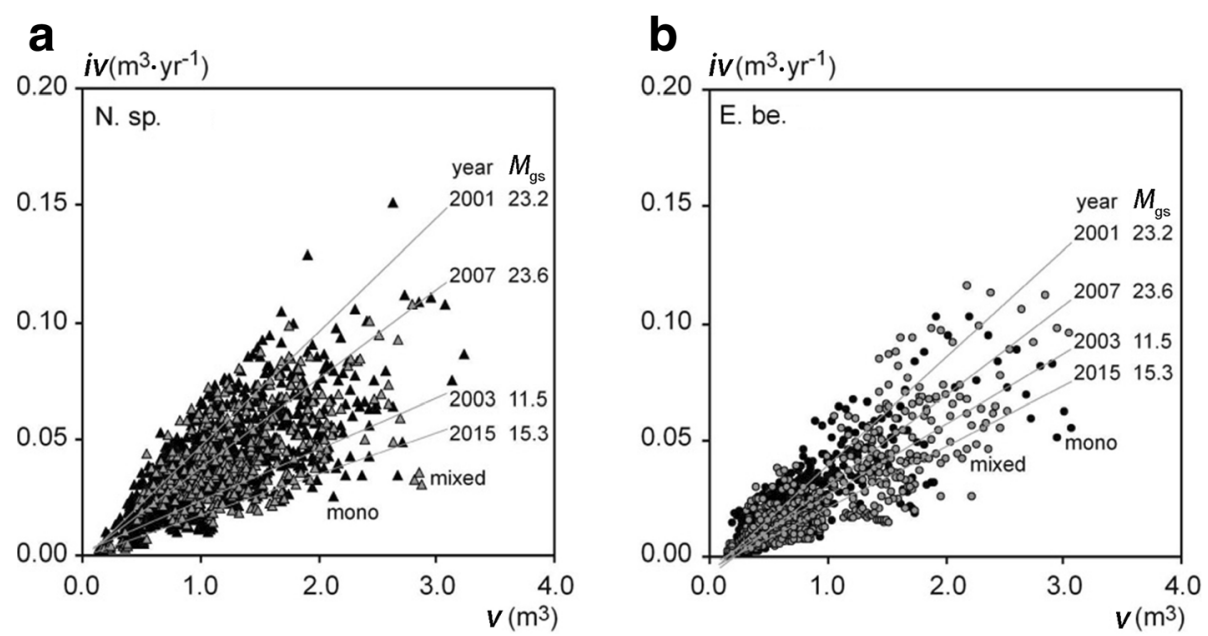

Fig. 4 The relationship between tree volume growth (iv) and tree volume (v) represented by the iv-v line is steeper for (a) Norway spruce than for (b) European beech and for both species steeper in moist years (e.g., 2001, 2007) than in dry years (e.g., 2003, 2015). For this evaluation we pooled the trees of the monospecific and mixed species plots

While Fig. 4 just presents the linear model fits of $i v=$ $a+b v$ for selected years and spruce and beech without making a difference between mixed and monospecific stands, the model was fitted for each year and additional combinations of species and mixed/monospecific stand (see methods section, Table 4). Accordingly, Additional file 1: Tables S1 and S2 show the corresponding fit results for Norway spruce and European beech, respectively, in total (mixed and monospecific together). Additional file 1: Tables S3 and S4 show the same for monospecific stands, while Additional file 1: Tables S5 and $\mathrm{S} 6$ relate to both species in mixed stands. All regressions were significant at level $p<0.001$.

The parameters of these regressions were used for further analysis of any general dependency of the sizeasymmetry from the annual water availability (see methods section). The following analysis of growth partitioning among trees of different sizes depending on water availability were based on the intercepts $a$ and slopes $b$ of those regressions.

Table 6, upper part, shows that the intercept of the $i v-v$ relationship mostly decreases and the slope increases with increasing Martonne index $M_{\mathrm{gs}}$ (see parameter estimates for $b_{0}$ and their significance in Table 6). The lower part of Table 6 presents the resulting linear relationships between intercept and slope and $M_{\mathrm{gs}}$ for all investigated groups. Figure 5 shows these general findings exemplarily for Norway spruce and European beech, both without a distinction by mixed or monospecific stands. The trend lines in Fig. 5a and b, resulting from the fitted models after Eqs. $2 \mathrm{a}, 2 \mathrm{~b}$ and Table 6 corroborate that higher water availability, indicated by high $M_{\mathrm{gs}}$ values, increases the slope and decreases the intercept of the $i v-v$ relationship. This indicates a tendency towards more size-asymmetric growth partitioning between the trees of a population. Low water supply results in shallower slopes and higher intercepts of the $i v-v$ relationships which means a general tendency towards a size-symmetric growth partitioning of the trees in the populations in dry years. However, except from the significantly higher intercept of Norway spruce compared with European beech we found no significant group differences (Table 6, lower part). Figure 6 illustrates this effect exemplarily for the model for all Norway spruces. With increasing Martonne index the asymmetry of competition increases, whereas water limitation equalizes the growth partitioning between different-sized. Notice that the $i v-v$ relationships intersect and that small trees suffer less from water limitation or even benefit compared with tall trees. If the $i v-v$ relationships for different Martonne index values would all run through the origin of the coordinate system and just differ in their slopes, this would indicate the same relative growth loss for trees of different sizes. However, the finding that water limitation can change (increase) intercept and slope (decrease) reveals the tendency to more symmetric resource and growth partitioning under drought and the partitioning in favour of small trees in especially in case of Norway spruce.

\section{Q3: Growth dominance and representativeness of dominant trees depending on water availability}

The resistance $(R t)$ values printed bold in Table 7 indicate a significant growth decrease below the pre-drought level. Except the subdominant trees in 2015 all spruces significantly reduced their growth due to drought in 2003 and 2015. Dominant spruces were significantly less drought resistant than their subdominant neighbours. In relation to the 3-year-period before drought dominant 
Table 6 Upper part: Results of the pairwise comparisons by fitting Eqs. 2a, 2b (corresponding to Q2)

\begin{tabular}{|c|c|c|c|c|c|c|c|c|c|c|}
\hline \multicolumn{11}{|c|}{ Pairwise comparisons with regression models after Eq. 1} \\
\hline Comparison & $a_{0}$ & SE & $a_{1}$ & SE & $b_{0}$ & SE & $b_{1}$ & SE & $R^{2}$ & $p$ (model) \\
\hline Intercept N.sp. all vs. E.be. all & $0.0068^{*}$ & 0.0030 & $-0.0103^{*}$ & 0.0044 & $-0.0005^{* *}$ & 0.0002 & 0.0004 & 0.0002 & 0.48 & 0.000 \\
\hline Slope N.sp. all vs. E.be. all & 0.0018 & 0.0111 & 0.0225 & 0.0157 & $0.0017^{* *}$ & 0.0005 & -0.0013 & 0.0008 & 0.27 & 0.013 \\
\hline Intercept N.sp. mono vs. N.sp. mixed & 0.0083 & 0.0049 & -0.0077 & 0.0069 & $-0.0006^{*}$ & 0.0002 & 0.0006 & 0.0003 & 0.46 & 0.000 \\
\hline Slope N.sp. mono vs. N.sp. mixed & 0.0000 & 0.0123 & 0.0067 & 0.0174 & $0.0019^{* *}$ & 0.0006 & -0.0007 & 0.0009 & 0.38 & 0.001 \\
\hline Intercept E.be. mono vs. E.be. mixed & -0.0008 & 0.0040 & -0.0044 & 0.0056 & -0.0001 & 0.0002 & -0.0001 & 0.0003 & 0.54 & 0.000 \\
\hline Slope E.be. mono vs. E.be. mixed & 0.0230 & 0.0121 & 0.0014 & 0.0171 & 0.0006 & 0.0006 & -0.0001 & 0.0008 & 0.05 & 0.583 \\
\hline \multicolumn{11}{|c|}{ Resulting linear models intercept $=a+b M_{\mathrm{gs} \text {, }}$ slope $=a+b M_{\mathrm{gs}}$. } \\
\hline Category & $a$ & $b$ & & diff & & & & & & \\
\hline Intercept N.sp. all & 0.0068 & -0.0005 & & A & \multicolumn{6}{|c|}{ diff $A$ is due to a difference in intercept only $(p=0.010)$} \\
\hline Intercept E.be. all & -0.0034 & -0.0001 & & A & & & & & & \\
\hline Slope N.sp. all & 0.0018 & 0.0017 & & & & & & & & \\
\hline Slope E.be. all & 0.0243 & 0.0005 & & & & & & & & \\
\hline Intercept N.sp. mono & 0.0083 & -0.0006 & & & & & & & & \\
\hline Intercept N.sp. mixed & 0.0006 & 0.0000 & & & & & & & & \\
\hline Slope N.sp. mono & 0.0000 & 0.0019 & & & & & & & & \\
\hline Slope N.sp. mixed & 0.0067 & 0.0013 & & & & & & & & \\
\hline Intercept E.be. mono & -0.0008 & -0.0001 & & & & & & & & \\
\hline Intercept E.be. mixed & -0.0052 & -0.0002 & & & & & & & & \\
\hline Slope E.be. mono & 0.0230 & 0.0006 & & & & & & & & \\
\hline Slope E.be. mixed & 0.0244 & 0.0005 & & & & & & & & \\
\hline
\end{tabular}
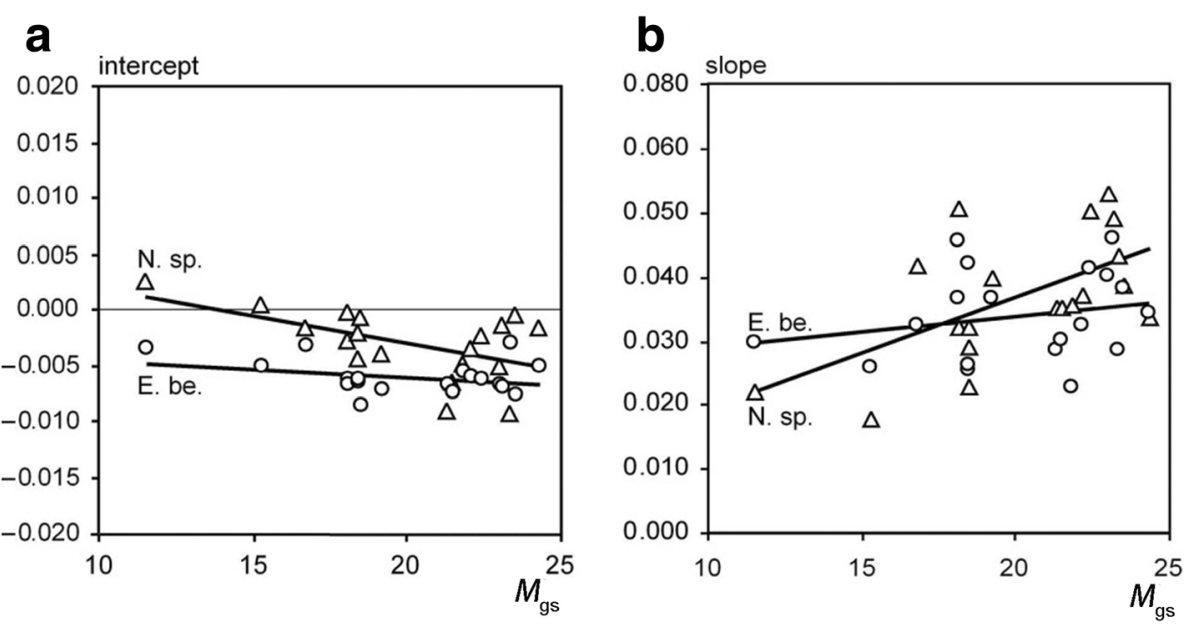

Fig. 5 Dependency of (a) the intercept $a$, and (b) the slope $b$ of the equation $i v=a+b v$ on the growing-season Martonne index $M_{\mathrm{gs}}$ fitted by linear models (Eqs. 2a and 2b) for Norway spruce and European beech (see Table 6 for statistical fit results). Water availability, $M_{\mathrm{gs},}$ mostly decreases the intercept and increases the slope of the annual and inter-individual $i v-v$ relationship. This indicates an increase of size-asymmmetric competition with increasing water availability and a more equal growth distribution between the trees in a stand in dry periods. For this evaluation we pooled the trees of the monospecific and mixed species plots 


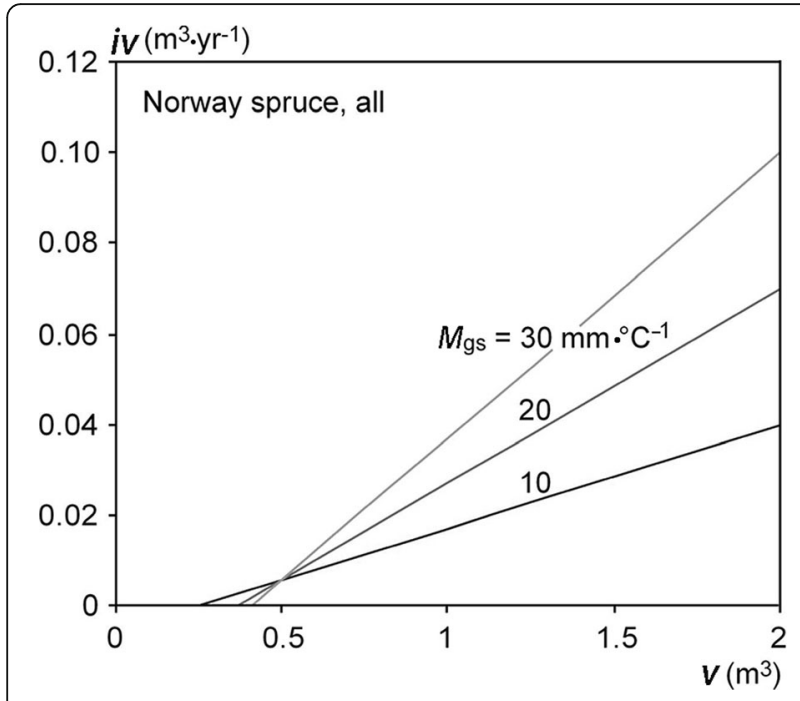

Fig. 6 Relationship between stem volume growth, iv, and stem volume, $v$, according to the fitted intercept and slope models for all Norway spruces (mixed and monospecific stands together, see Table 6). The graph shows the $i v-v$ relationship for Norway spruce in dry, medium and moist years, characterised by Martonne index values in the growing season of $M_{\mathrm{gs}}=10,20$ and $30 \mathrm{~mm} \cdot{ }^{\circ} \mathrm{C}^{-1}$

spruces reduced their stem volume growth in 2003 and 2015 by $50 \%$ and $46 \%$, respectively ( $R t=0.50$ and 0.54 ). Compared to the mean tree (tree with the mean stem volume) in the stand, growth reduction of dominant spruces was about 8-17 percentage points stronger.

Subdominant spruces, in contrast, were more resistant and reduced the growth less or not at all in 2003 and 2015 ( $R t=0.64$ and 1.01). Because of their higher resistance the drought-induced relative growth losses on stand level were lower than observed at the dominant trees only.

In case of beech the average drought resistance in 2003 and 2015 was much higher ( $R t=0.87$ and 1.02) than for spruce, the growth losses being hardly relevant. The bold $R t$ values in Table 7 reveal a significant growth reduction due to drought just for the dominant beeches in 2003 and $2015(R t=0.71,0.94)$ and the overall group mean in 2003 $(R t=0.87)$. Subdominant beeches showed no significant growth reductions due to drought. Dominant beeches represent the mean stand reaction pattern on the severe droughts in 2003 and 2015 quite well. In case of beech we found no significant differences between the groups.

Figure $7 \mathrm{a}$, and $\mathrm{b}$, shows that the $10 \%$ tallest trees produce $20 \%-30 \%$ of the total stand volume growth in case of Norway spruce and $30 \%-40 \%$ in case of European beech. The $10 \%$ smallest trees contribute just $0.5 \%-3.0 \%$ and $0.5 \%-1.0 \%$ to the total stand volume in case of Norway spruce and European beech, respectively. So, the $10 \%$ small ones contribute about a tenth of the taller ones to the total stand volume growth.

In case of Norway spruce, dry years have an opposite effect on the relative shares which the small and tall trees have of the total stand volume growth (Fig. 7a). While the share the $10 \%$ smallest trees have at the total stand volume growth increases in dry years, the share of the $10 \%$ tallest trees decreases. Drought obviously affects the volume growth share of tall trees in a stand stronger in terms of growth reduction than the small trees. In case of Norway spruce the series of dry years possibly triggers a continuous increase of the volume growth share of the small trees in the whole study period, while the share of the tall trees continuously decreases from 1998 to 2016. For European beech the trend of repartitioning in favour of the small trees, if any, is far less pronounced than for Norway spruce (Fig. 7b).

The Growth Dominance Coefficient (GDC) values being smaller or - in case of Norway spruce - even below zero in dry years (e.g., 2003 and 2015) and greater in normal and wet years (e.g., 2001, 2007) substantiate growth partitioning in favour of small trees when the stands suffer drought stress (Fig. 8). Table 8 shows the results of the regression analysis that relates $G D C$ with the de Martonne index (Eq. 3) for all analysed strata. The by-trend increase of GDC with increasing Martonne Index in the growing season, $M_{\mathrm{gs}}$, indicates that growth dominance, i.e., the contribution of the dominant trees to the stand volume growth, increases with the water availability. The other way round the share the 10\% small trees have of the total stand volume growth increases with shortage of water. This tendency is only significant for Norway spruce in a monospecific

Table 7 Drought resistance, $R$ t, in terms of stem volume growth of trees in the drought years 2003 and 2015 in relation to the before-drought period (2000-2002 and 2012-2014, respectively). Group means and standard errors (SE) for all trees, the 100 smallest (subdominant) and the 100 tallest (dominant) trees per hectare

\begin{tabular}{|c|c|c|c|c|}
\hline Species & Size group & $n$ & 2003 & 2015 \\
\hline \multirow[t]{3}{*}{ Norway spruce } & subdominant & 5 & $\rightarrow 0.64( \pm 0.04)$ & $\longrightarrow 1.01( \pm 0.04) \leftarrow$ \\
\hline & dominant & 5 & $\rightarrow 0.50( \pm 0.02)$ & $\longrightarrow \mathbf{0 . 5 4}( \pm 0.05)$ \\
\hline & all & 61 & $\rightarrow 0.58( \pm 0.01)$ & $\rightarrow 0.71( \pm 0.02)$ \\
\hline \multirow[t]{3}{*}{ European beech } & subdominant & 5 & $0.98( \pm 0.08)$ & $0.85( \pm 0.11)$ \\
\hline & dominant & 5 & $0.71( \pm 0.05)$ & $0.94( \pm 0.03)$ \\
\hline & all & 64 & $0.87( \pm 0.03)$ & $1.02( \pm 0.04)$ \\
\hline
\end{tabular}

Arrows connecting group means indicate significant differences at the level $p<0.05$. Bold $R t$-values indicate significant growth reduction below the pre-drought level 
a

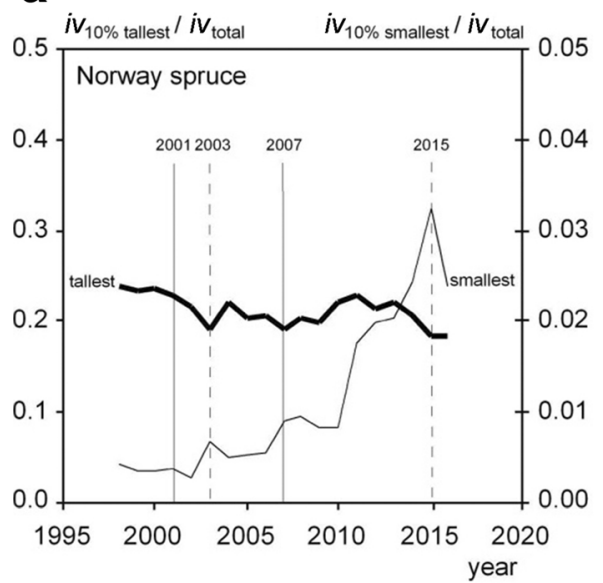

b

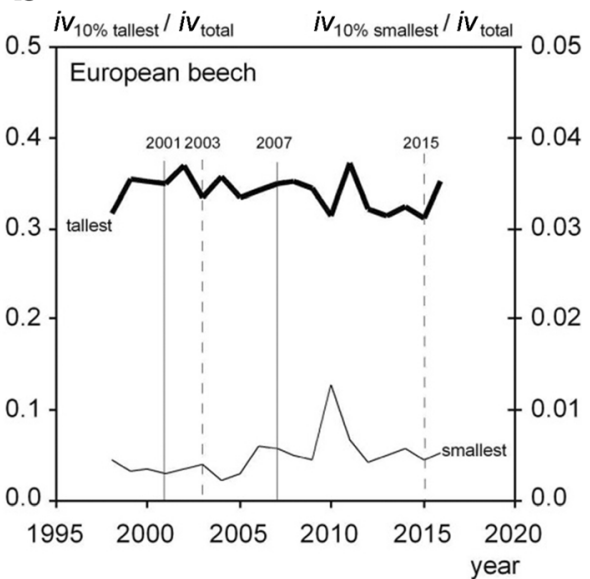

Fig. 7 Shares of the 10\% tallest and 10\% smallest trees at stand volume growth (iv). Dry years $(2003,2015)$ and wet years (2001, 2007) are highlighted. a For Norway spruce the share of the 10\% smallest trees of the total stand growth varies between $0.5 \%$ and $3.0 \%$, and increases in dry years as 2003 and 2015. The share of the 10\% tallest varies between $20 \%$ and 30\% and decreases in dry years. b For European beech the share of the $10 \%$ smallest trees of the total stand growth varies between $0.5 \%$ and $1.0 \%$. The share of the $10 \%$ tallest trees varies between $30 \%$ and $40 \%$, the reactions on drought are less pronounced than for spruce

environment (parameter $b_{0}$ in Table 8 , upper part), but it leads to a consistent positive slope of the relationship $G D C=a+b M_{\mathrm{gs}}$ for all analysed categories (parameter $b$ in Table 8, lower part). Notice that the level of growth dominance, the intercept $a$ in the equation above, was generally higher in European beech than in Norway spruce (Fig. 8, parameter $a$ in Table 8, lower part).
There were significant differences in this level of growth dominance between Norway spruce and European beech and also between European beech in mixed versus pure stands (Table 8 , lower part). Based on the parameters $a$ and $b$ shown in Table 8 (lower part), Fig. 8 shows the trend lines for the relationship between $G D C$ and $M_{\mathrm{gs}}$ for the various groups.

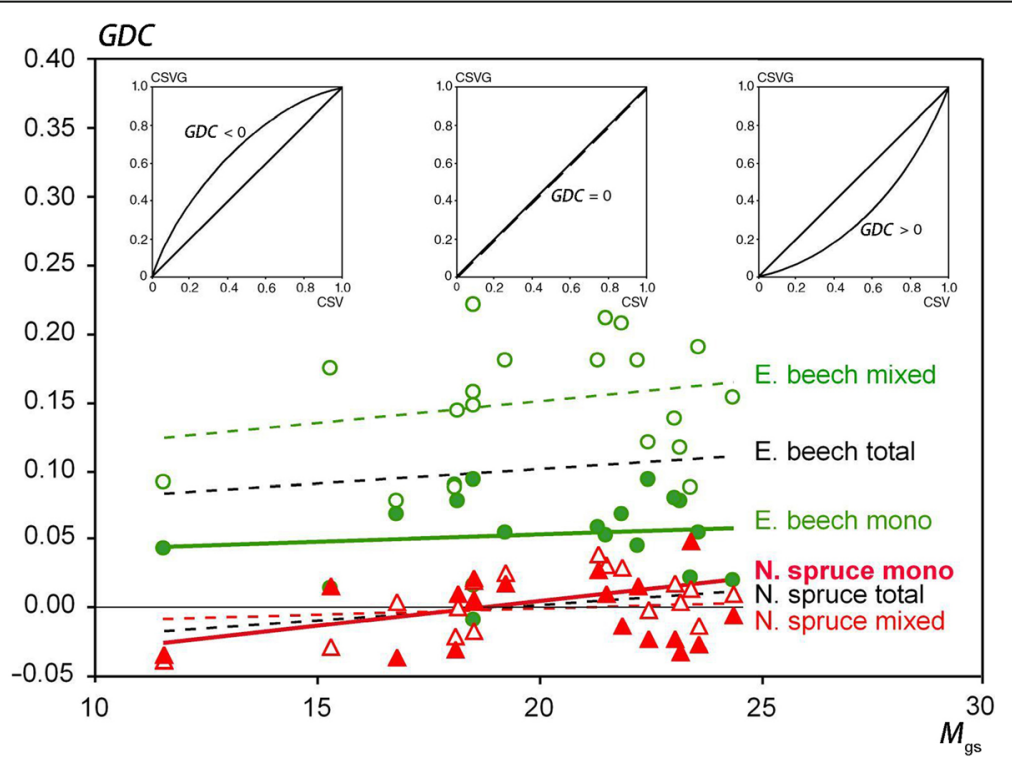

Fig. 8 The increase of the growth dominance coefficient, GDC, with increasing water availability, $M_{\mathrm{gs}}$, indicates that under dry conditions small trees have a larger share of the total stand volume growth whereas under moist conditions the share of dominant trees increases. The insets in the upper part of the graph illustrate how the curve of cumulative stem volume growth over the cumulative stem volume changes with increasing water availability (from left to right) 
Table 8 Upper part: Results of the pairwise comparisons by fitting Eq. 3 (corresponding to Q3)

\begin{tabular}{|c|c|c|c|c|c|c|c|c|c|c|}
\hline \multicolumn{11}{|c|}{ Pairwise comparisons with regression models after Eq. 1} \\
\hline Comparison & $a_{0}$ & SE & $a_{1}$ & SE & $b_{0}$ & SE & $b_{1}$ & SE & $R^{2}$ & $p$ (model) \\
\hline N.sp. all vs. E.be. all & -0.0425 & 0.0339 & $0.1004^{* * *}$ & 0.0106 & 0.0022 & 0.0016 & n.a. & n.a. & 0.55 & 0.000 \\
\hline N.sp. mono vs. N.sp. mixed & $-0.0668^{*}$ & 0.0321 & 0.0469 & 0.0454 & $0.0036^{*}$ & 0.0016 & -0.0027 & 0.0022 & 0.16 & 0.112 \\
\hline E.be. mono vs. E.be. mixed & 0.0101 & 0.0388 & $0.0972^{* * *}$ & 0.0122 & 0.0022 & 0.0019 & n.a. & n.a. & 0.65 & 0.000 \\
\hline \multicolumn{11}{|c|}{ Resulting linear models $G D C=a+b M_{\mathrm{gs}}$} \\
\hline Category & $a$ & $b$ & & diff & & & & & & \\
\hline N.sp. all & -0.0425 & 0.0022 & & A & \multicolumn{6}{|c|}{ diff $A$ is due to a difference in the intercept $(p=0.000)$} \\
\hline E.be. all & 0.0579 & 0.0022 & & A & \multicolumn{6}{|c|}{ diff $B$ is due to a difference in the intercept $(p=0.029)$} \\
\hline N.sp. mono & -0.0668 & 0.0036 & & & & & & & & \\
\hline N.sp. mixed & -0.0199 & 0.0001 & & & & & & & & \\
\hline E.be. mono & 0.0101 & 0.0022 & & B & & & & & & \\
\hline E.be. mixed & 0.0972 & 0.0022 & & B & & & & & & \\
\hline
\end{tabular}

In some cases, the parameter $b_{1}$ was left out due to model overfitting (entry n.a.). Lower part: Linear models for the different species/stand categories resulting from combining the corresponding parameter estimates from the upper part. If two categories have the same letter under 'diff', their linear models differ significantly due to the significances shown in the upper part of the table. Not all possible combinations of categories were tested against each other; see column 'comparison' for the performed tests. N.sp, Norway spruce, E.be European beech. Significant differences of the parameters between the groups are indicated by the levels of significance $\left({ }^{*} p<0.05,{ }^{* *} p<0.01,{ }^{* * *} p<0.001\right)$

\section{Discussion}

This study was motivated by the lately increasing number of drought years and the need to adapt forest management to climate change. However, beyond this aspect, the revealed dependency of growth partitioning from the water availability is of general interest. It helps to better understand and model the influence of water availability on forest stand structures and dynamics. In addition, our results could be of relevance for forest biomonitoring under changing climate conditions. Other factors such as fructification (Seifert and Müller-Starck 2009) or ozone (Pretzsch et al. 2010) might also have contributed to the low growth in 2011 but were neither noticed nor measured.

\section{Evidence and explanation of modified growth partitioning under drought stress}

Climate change and especially recent drought events triggered many studies showing that trends and events of environmental conditions can reduce (Dobbertin 2005; Zang et al. 2012) but also accelerate tree growth (Kauppi et al. 2014; Pretzsch et al. 2014). The studies show that drought resistance is very species specific (Friedrichs et al. 2009; Pretzsch et al. 2013; Zang et al. 2014), especially that deep rooting species such as sessile oak or Scots pine (Abrams 1990; Irvine et al. 1998) are more drought resistant than shallow rooting ones like Norway spruce or Douglas-fir (Bréda et al. 2006). Isohydric species such as Norway spruce, Scots pine or silver-fir suffer more but recover quicker under short drought events, while anisohydric species such as European beech or sessile oak decrease less in growth but may suffer by longer lasting drought events (McDowell et al. 2008; Hartmann 2011). Drought stress may decrease with increasing age and size as trees get better access to water in deeper soil layers by their extended root systems (Abrams 1990; Bréda et al. 2006). Other works found that resilience and resistance may decrease with size due to longer xylem path and hydraulic and stomatal limitation (Ding et al. 2017).

New and interesting is our finding that drought not only severely reduces tree and stand growth but also redistributes the growth in favour of smaller trees. Thus, while moist years enhance the dominance of large trees, the distribution turns in favour of smaller ones with decreasing water availability (Fig. 9). This applies especially for Norway spruce. Beech loses less stand volume growth and keeps the growth distribution between tall and small trees more constant.

This species specific reaction pattern might be explained by the isohydric character (McDowell et al. 2008; Hartmann 2011) of Norway spruce. On drought and strong exposition to heat and direct solar radiation tall spruces may react with stomata closure and reduction of transpiration and growth, while smaller neighbours might even benefit from both, their shade and their reduced water consumption. Beeches, in contrast, have an anisohydric character and go on transpiring and growing even under dry conditions in both the dominant and subdominant stand layer. So, growth differences between small and tall trees in moist and or dry years are less pronounced for European beech.

Hara (1993), Schwinning and Weiner (1998), and Wichmann (2001) hypothesize that under moist conditions the tall trees in a stand can pre-empt the light on the expense of their small neighbours due to their 
a

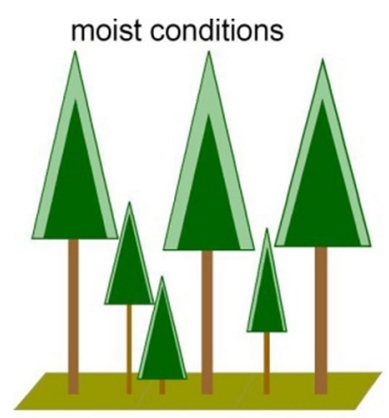

b

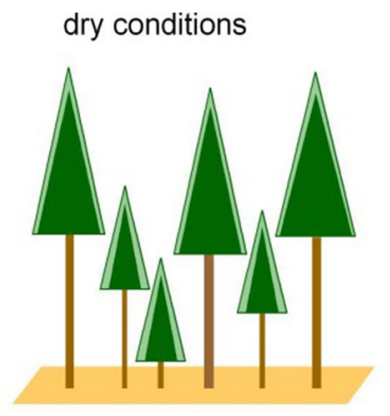

C growth

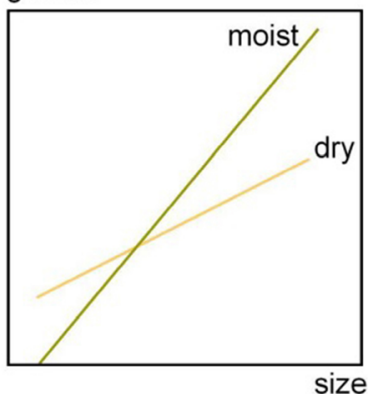

Fig. 9 Inter-individual growth partitioning between trees of different social positions in a stand depending on the current water availability. a In moist years, dominant trees can benefit from their preferential access to light and achieve asymmetric competition and overproportional growth rates compared with smaller neighbours. b Drought favours the growth of smaller trees in a stand on the expense of the socially dominating neighbours. c The relationship between tree size and size growth can be steep and reflect size-asymmetric dominance of tall trees in moist years. It may become shallow and reflect more symmetric growth partitioning under drought. The light green envelopes of the schematic tree crowns represent the individual growth rates of the trees

superior height. The tall trees intercept more light and grow disproportionally more than the small ones as due to their size they achieve both a higher share of light interception and, by shading and suppressing their smaller neighbours, a reduction of their resource consumption such as water and mineral nutrients.

In dry and warm years a superior size may turn into a disadvantage, as large trees are more exposed to heat and hydraulic stress than their smaller neighbours. When the growth of tall trees gets water limited they do no longer benefit from their advantageous access to light. When forced to close their stomata, they consume less water and mineral nutrients; both in turn improves the growing conditions of the small trees which may benefit in addition by being shaded. The analysed stands followed such reactions patterns, and our statistical analyses suggest the relationship between water and growth partitioning as the main cause.

Whereas there were clear species specific reaction patterns, we found just tendencies, but no significant differences between monospecific stands and mixed-species settings regarding the water dependency of growth partitioning. A larger sample of trees in both groups might have yielded clearer results.

Relevance for understanding and modelling stand dynamics While most studies deal with dominant trees, the drought reaction of smaller trees is less well known. Trees with inferior social positions may on the one hand benefit from being shaded in dry years, from the reduced water consumption of tall neighbours with isohydric behaviour (Goisser et al. 2016), or from their rooting closer to the surface which means better access to occasional rainwater in summer (Flanagan et al. 1992). On the other hand, being subdominant may mean less access to water and less stemflow in favour of the roots, limited access to ground water, or less water availability when stocking beside anisohydric neighbours which are continuously exploiting the available water supply (Wullschleger et al. 1998; Pretzsch et al. 2014; Grote et al. 2016). So far, there is no accepted general pattern of how subdominant trees come off under drought in relation to dominant and predominant trees.

Most growth models allocate the growth among the trees of a population in relation to the light availability. E.g. individual tree models use competition indices for quantifying light availability of individual trees and allocate exponentially more growth to tall than to small trees. The assumption of light-dependent growth partitioning does not apply to dry years when growth of dominant trees is reduced because of drought stress. Neglect of the water limitation of tall trees in dry years may result in too asymmetric growth partitioning and too heterogeneous forest structures when modelling stand dynamics (Seifert et al. 2014).

The fact that drought years reduce the growth of tall trees more strongly than the growth of small trees has an effect on the structure of forest stands. If small trees gain in relation to tall trees, they stay in the game and can widen the size distribution and vertical structuring. In both, monospecific and mixed-species stands, drought years promote the small trees in relation to the dominant trees and generate wider size differentiation and vertical heterogeneity. Without water limitation, trees are mainly competing for light. Tall trees can pre-empt the light, exert size-asymmetric competition and may suppress and outcompete their smaller neighbours. This strongly asymmetric competition turns into a more balanced competition in drought years, as small trees are more favoured than in normal years and may impede 
the recovery of their tall neighbours. The effect is of course not strong enough to completely change the hierarchy between small and tall trees, however, it can contribute to an increased persistence of small trees in the understorey with the above-mentioned effects on stand structure.

This structuring effect of dry years is reflected by the generally richer size differentiation and vertical heterogeneity on dry compared to moist sites (Zeller et al. 2018). The relative benefit of small trees by drought years means a reduction of their mortality and accumulation of such trees in the understorey. Their additional water consumption may have a negative effect on the recovery of the tall trees in the years after the drought stress. This reduction of the recovery of the tall trees may further result in a relative benefit of the small trees, size differentiation, and vertical structuring.

\section{Methodological considerations}

The study was based on volume growth derived from stem diameter, tree height and form factors; this implies the assumption that trees keep to their normal form and increment allocation pattern along the stem axis in dry years. However, the studies by (Mette et al. 2015; Trouvé et al. 2015) showed that trees can reduce their growth at the height of $1.30 \mathrm{~m}$ more than in higher stem parts and thus shift their stem shape pattern. This means that we may overestimate the growth reduction in dry years as trees might reduce their diameter growth in the lower stem but still grow proportionally better in higher stem sections. We also neglect any possible drought effects on wood density and total biomass. When including these aspects, the results in terms of absolute growth losses may slightly change, however, the revealed relations between the reaction of small and tall trees will probably still have the same trend as the above-mentioned effects will be similar for all trees of the stand. As annual records of stand growth over long times are rare we based our study on just one experiment. It is representative for sites which are rather well supplied with water and nutrients in normal years, but strongly water limited in drought years. The site conditions, stand age phase (50-70 years), and species composition of the experiment represent many monocultures and mixed species stands in Central Europe quite well.

Relevance for monitoring health and vitality in forest stands In order to eliminate competition effects, measurements for monitoring growth responses on drought or other kind of stress are mostly based on dominant trees of forest stands (Rigling et al. 2002; Rais et al. 2014). The growth response of the dominant trees is supposed to reflect the relative growth reduction of the total stand. This is correct if the relative growth reduction is similar for trees of all sizes and if the stress does not change the partitioning. We found, however, that in the drought years 2003 and 2015 the growth of dominant Norway spruces decreased to $50 \%$ or $54 \%$ of the pre-drought period. The trees on average decreased just to $58 \%$ and $71 \%$, respectively; the small trees decreased even less or not at all (64\% and 101\%). So, if quantifications of stress responses and growth losses would be based just on dominant trees, such losses would be considerably overestimated. For monitoring stress responses of tree populations also the small trees should be measured, cored, or equipped with permanent increment girth tapes.

\section{Silvicultural implications}

Many current silvicultural guidelines strive for more heterogeneous stands (Utschig et al. 2011; Pretzsch and Zenner 2017) as they may provide many ecosystem goods and services (Biber et al. 2015; Poorter et al. 2015; Mensah et al. 2016; Dieler et al. 2017) better than monocultures. The finding that small trees benefit in relation to tall trees from dry years and on dry sites (see also Pretzsch and Biber 2010) means that structural heterogeneity, as aimed at by many modern silvicultural guidelines, is easier to maintain on poor dry sites. A partitioning in favour of small trees may mean that small trees keep in the play and compensate growth losses of the tall ones, thus buffering stand productivity in unfavourable years. From this point of view removing the small trees would mean a reduction of both, structural heterogeneity and buffer capacity at stand level.

On the other hand, silvicultural decisions should also take into account that small trees might exert undesired effects on dominant trees under drought stress conditions; i.e. in years with ample water supply or on continuously moist sites where tree growth is mainly limited by light, small trees may contribute to stand growth without disadvantageous effects on the dominant trees. So, their elimination may hardly improve the growth of the dominant trees but lower the total stand growth as described by Pretzsch (2005). In dry years or on dry sites, in contrast, those small trees may increase the competition for water and slow down the growth of the tall trees. As they use considerable amounts of water, they may aggravate the drought stress of their taller neighbours and their recovery. So, their removal by thinning might homogenize the stand structure but increase the growth of the valuable future crop trees under stress conditions (Aussenac and Granier 1988; Martín-Benito et al. 2010). Consequently, on dry sites, the thinning of the small trees may increase the stand growth as described by the uni-modal stand density-growth relationship (Assmann 1970). In wet years and on moist sites small trees can still considerably contribute to stand growth; while their contribution to stand growth is 
greater in dry years and on dry sites, they can become serious competitors to the dominant trees under such conditions. Their elimination may reduce drought stress and bark beetle damage (Wermelinger 2004) and increase stand growth as their tall neighbours can use the water more efficiently (Sohn et al. 2013; Gebhardt et al. 2014). So, if dry years occur frequently, the elimination of small trees will be favourable for the future crop trees on the expense of stand structure. However, if the frequency of dry years is low, their elimination will homogenize stand structure without beneficial effects for the remaining trees. Of course, structural heterogeneity, habitat diversity, risk prevention, potential transformation to uneven-aged structures, are good reasons why small trees may be left in a stand (del Río et al. 2017). However, in view of climate change, elimination of small trees may strengthen growth and resistance of tall trees under water limited conditions.

\section{Conclusions}

In mature monospecific and mixed stands of Norway spruce and European beech we found as a general pattern that drought can alter the growth partitioning in favour of small at the expense of tall trees. This can result in a more even growth distribution between trees of different sizes and more heterogeneous stand structures under water limitation compared with moist conditions. Whereas this behaviour was evident and more pronounced in Norway spruce than European beech, we found just tendencies, but no significant differences between monospecific stands and mixed-species stands regarding this behaviour. Because of the far-reaching consequences of this water-dependent growth partitioning and population dynamics, future studies should further explore the relationship between water supply and inter-individual growth partitioning on a broader data base. The additional effect of stand density reduction and tree species selection would be of special interest for forestry. Whereas we studied the effect of episodic drought so far, ongoing water retention experiments and transect studies along gradients of water availability might reveal whether more frequent drought events and continuous drought stress may result in stand dynamics as known from permanently dry and continental areas of, e.g., central Spain, southwest USA, and inner South Africa.

\section{Additional file}

Additional file 1: Electronical Supplement Tables S1-S6. (DOCX 44 kb)

\section{Abbreviations}

BA: Basal area; GC: Gini coefficient; GDC: Growth dominance coefficient; iv: Stand volume growth; iv-v relationship: Inter-individual relationship between the tree volume and tree volume growth within a population; M: Aridity index after de Martonne (de Martonne 1926); Mgs: Martonne index based on the precipitation and temperature within the growing season;
OLS: Ordinary least squares; Rt: Index of drought resistance; v: Standing volume stock

\section{Acknowledgements}

The authors thank the European Union for funding of the project "Management of mixed-species stands. Options for a low-risk forest management (REFORM)" (FKZ: 2816ERA02S). We further thank the Bayerische Staatsforsten (BaySF) for providing the experimental plot, the Bavarian State Ministry for Nutrition, Agriculture, and Forestry for permanent support of the project W 07 "Long-term experimental plots for forest growth and yield research" (\# 783122209-2013) and the German Science Foundation (DFG) for providing the funds for the project PR 292/12-1 "Tree and stand-level growth reactions on drought in mixed versus pure forests of Norway spruce and European beech". Thanks are also due to Lothar Zimmermann for providing the meteorological data from the nearby forest climate station Kranzberg Forest/Freising, to Ulrich Kern for the graphical artwork, and to two anonymous reviewers for their constructive criticism.

\section{Funding}

- Funding Source: European Union; Award Number 281116ERA02S; Recipient: Hans Pretzsch; Project Title: "Management of mixedspecies stands. Options for a low-risk forest management (REFORM)".

- Funding Source: Bayerisches Staatsministerium für Ernährung, Landwirtschaft und Forsten (Bavarian State Ministry for Nutrition, Agriculture, and Forestry); Award Number W07 7831-22209-2013; Recipient: Hans Pretzsch; Project Title: "Long-term experimental plots for forest growth and yield research".

- Funding Source: Deutsche Forschungsgemeinschaft (German Science Foundation); Award Number PR 292/12-1; Recipient: Hans Pretzsch; Project Title: "Tree and stand-level growth reactions on drought in mixed versus pure forests of Norway spruce and European beech".

\section{Availability of data and materials}

The materials described in the manuscript including all relevant raw data will be freely available upon request from the corresponding author.

\section{Legal statement}

All research work reported in this study was performed in accordance with all relevant legislation and guidelines.

\section{Authors' contributions}

HP initiated the study, conceptualized the study design, and wrote the draft version of the manuscript. GS conducted the field work, the laboratory work, and data analysis. PB supported the statistical analysis and revised the manuscript. All authors read and approved the final manuscript.

Ethics approval and consent to participate

Not applicable; this study does not involve human subjects, human material, or human data.

\section{Consent for publication}

Not applicable.

\section{Competing interests}

The authors declare that they have no competing interests.

Received: 8 January 2018 Accepted: 14 March 2018

Published online: 02 April 2018

\section{References}

Abrams MD (1990) Adaptations and responses to drought in Quercus species of North America. Tree Physiol 7:227-238

Assmann E (1970) The principles of forest yield study. Pergamon Press, Oxford, New York

Assmann E, Franz F (1963) Vorläufige Fichten-Ertragstafel für Bayern. Forstliche Forschungsanstalt München, Institut für Ertragskunde, München

Aussenac G, Granier A (1988) Effects of thinning on water stress and growth in Douglas-fir. Can J For Res 18(1):100-105 
Biber P (2013) Kontinuität durch Flexibilität-Standardisierte Datenauswertung im Rahmen eines waldwachstumskundlichen Informationssystems. Allg Forst Jagdztg 184:167-177

Biber P, Borges JG, Moshammer R, Barreiro S, Botequim B, Brodrechtová Y, Brukas V, Chirici G, Cordero-Debets R, Corrigan E, Eriksson LO, Favero M, Galev E, Garcia-Gonzalo J, Hengeveld G, Kavaliauskas M, Marchetti M, Marques S, Mozgeris G, Navrátil R, Nieuwenhuis M, Orazio C, Paligorov I, Pettenella D, Sedmák R, Smreček R, Stanislovaitis A, Tomé M, Trubins R, Tuček J, Vizzarri M, Wallin I, Pretzsch H, Sallnäs O (2015) How sensitive are ecosystem Services in European Forest Landscapes to Silvicultural treatment? Forests 6(5):1666-1695. https://doi.org/10.3390/f6051666

Biging GS, Dobbertin M (1995) Evaluation of competition indices in individual tree growth models. For Sci 41:360-377

Binkley D, Kashian DM, Boyden S, Kaye MW, Bradford JB, Arthur MA, Fornwalt PJ, Ryan MG (2006) Patterns of growth dominance in forests of the Rocky Mountains, USA. Forest Ecol Manag 236:193-201

Bréda N, Huc R, Granier A, Dreyer E (2006) Temperate forest trees and stands under severe drought: a review of ecophysiological responses, adaptation processes and long-term consequences. Ann Forest Sci 63:625-644

De Camino R (1976) Zur Bestimmung der Bestandeshomogenität. Allg Forst Jagdztg 147:54-58

de Martonne E (1926) Une nouvelle function climatologique: L'indice d'aridité. Meteorologie 2:449-459

del Río M, Oviedo JAB, Pretzsch H, Löf M, Ruiz-Peinado R (2017a) A review of thinning effects on scots pine stands: from growth and yield to new challenges under global change. Forest Syst 26(2):eR03S

del Río M, Pretzsch H, Ruíz-Peinado R, Ampoorter E, Annighöfer P, Barbeito I, Bielak K, Brazaitis G, Coll L, Drössler L, Fabrika M, Forrester DI, Heym M, Hurt V, Kurylyak V, Löf M, Lombardi F, Madrickiere E, Matović B, Mohren F, Motta R, den Ouden J, Pach M, Ponette Q, Schütze G, Skrzyszewski J, Sramek V, Sterba H, Stojanović D, Svoboda M, Zlatanow TM, Bravo-Oviedo A (2017b) Species interactions increase the temporal stability of community productivity in Pinus sylvestris-Fagus sylvatica mixtures across Europe. J Ecol 105(4):1032-1043

Dieler J, Uhl E, Biber P, Müller J, Rötzer T, Pretzsch H (2017) Effect of forest stand management on species composition, structural diversity, and productivity in the temperate zone of Europe. Eur J Forest Res 136(4):739-766

Ding H, Pretzsch H, Schütze G, Rötzer T (2017) Size-dependence of tree growth response to drought for Norway spruce and European beech individuals in monospecific and mixed-species stands. Plant Biol 19(5):709-719. https://doi.org/10.1111/plb.12596

Dobbertin M (2005) Tree growth as indicator of tree vitality and of tree reaction to environmental stress: a review. Eur J Forest Res 124(4):319-333. https://doi.org/10.1007/s10342-005-0085-3

Flanagan LB, Ehleringer JR, Marshall JD (1992) Differential uptake of summer precipitation among co-occurring trees and shrubs in a pinyon-juniper woodland. Plant Cell Environ 15:831-836

Franz F, Bachler J, Deckelmann E, Kennel E, Kennel R, Schmidt A, Wotschikowski U (1973) Bayerische Waldinventur 1970/71. Inventurabschnitt I: Großrauminventur Aufnahme- und Auswertungsverfahren. Forstliche Versuchsanstalt München, München

Friedrichs DA, Trouet V, Büntgen U, Frank DC, Esper J, Neuwirth B, Löffler J (2009) Species-specific climate sensitivity of tree growth in central-West Germany. Trees 23:729. https://doi.org/10.1007/s00468-009-0315-2

Gebhardt T, Häberle K-H, Matyssek R, Schulz C, Ammer C (2014) The more, the better? Water relations of Norway spruce stands after progressive thinning. Agric For Meteorol 197:235-243. https://doi.org/10.1016/j.agrformet.2014.05.013

Goisser M, Geppert U, Rötzer T, Paya A, Huber A, Kerner R, Bauerle T, Pretzsch H, Pritsch K, Häberle KH, Matyssek R, Grams TEE (2016) Does belowground interaction with Fagus sylvatica increase drought susceptibility of photosynthesis and stem growth in Picea abies? Forest Ecol Manag 375:268-278

Göttlein A, Baumgarten M, Dieler J (2012) Site conditions and tree-internal nutrient partitioning in mature European beech and Norway spruce at the Kranzberger Forst. Growth and Defence in Plants. Springer, Heidelberg, pp 193-211

Grote R, Gessler A, Hommel R, Poschenrieder W, Priesack E (2016) Importance of tree height and social position for drought-related stress on tree growth and mortality. Trees 30:1467-1482. https://doi.org/10.1007/s00468-016-1446-x

Häberle K-H, Weigt R, Nikolova PS, Reiter IM, Cermak J, Wieser G, Blaschke H, Rötzer T, Pretzsch H, Matyssek R (2012) Case study "Kranzberger Forst": growth and defence in European beech (Fagus sylvatica L.) and Norway spruce (Picea abies (L.) Karst.). Growth and Defence in Plants. Springer, Heidelberg, pp 243-271

Hara T (1993) Mode of competition and size-structure dynamics in plant communities. Plant Spec Biol 8:75-84

Hartmann H (2011) Will a 385 million year-struggle for light become a struggle for water and for carbon? - how trees may cope with more frequent climate change-type drought events. Glob Chang Biol 17(1):642-655. https://doi.org/ 10.1111/j.1365-2486.2010.02248.x

Irvine J, Perks MP, Magnani F, Grace J (1998) The response of Pinus sylvestris to drought: stomatal control of transpiration and hydraulic conductance. Tree Physiol 18:393-402. https://doi.org/10.1093/treephys/18.6.393

Johann K (1993) DESER-Norm 1993. Normen der Sektion Ertragskunde im Deutschen Verband Forstlicher Forschungsanstalten zur Aufbereitung von waldwachstumskundlichen Dauerversuchen. Proceedings Deutscher Verband Forstlicher Forschungsanstalten, Sektion Ertragskunde. UnterreichenbachKapfenhardt, pp 95-104

Jucker T, Avăcăriței D, Bărnoaiea I, Duduman G, Bouriaud O, Coomes DA (2016) Climate modulates the effects of tree diversity on forest productivity. J Ecol 104:388-398

Jucker T, Bouriaud O, Avacaritei D, Coomes DA (2014) Stabilizing effects of diversity on aboveground wood production in forest ecosystems: linking patterns and processes. Ecol Lett 17:1560-1569

Kauppi PE, Posch M, Pirinen P (2014) Large impacts of climatic warming on growth of boreal forests since 1960. PLoS One 9(11):e111340. https://doi.org/ 10.1371/journal.pone.0111340

Kramer H (1988) Waldwachstumslehre: Ökologische und anthropogene Einflüsse auf das Wachstum des Waldes, seine Massenund Wertleistung und die Bestandessicherheit. Verlag Paul Parey, Hamburg

Lloret F, Keeling EG, Sala A (2011) Components of tree resilience: effects of successive low-growth episodes in old ponderosa pine forests. Oikos 120: 1909-1920. https://doi.org/10.1111/j.1600-0706.2011.19372.x

LWF (2017) Die bayerischen Waldklimastationen (WKS). http://www.lwf.bayern.de/wks. Accessed 2 Aug 2017

Martín-Benito D, Cherubini P, Del Río M, Cañellas I (2008) Growth response to climate and drought in Pinus nigra Arn. Trees of different crown classes. Trees 22(3):363-373

Martín-Benito D, Del Río M, Heinrich I, Helle G, Canellas I (2010) Response of climate-growth relationships and water use efficiency to thinning in a Pinus nigra afforestation. Forest Ecol Manag 259(5):967-975

Martínez-Vilalta J, López BC, Loepfe L, Lloret F (2012) Stand-and tree-level determinants of the drought response of scots pine radial growth. Oecologia 168:877-888

McDowell N, Pockman WT, Allen CD, Breshears DD, Cobb N, Kolb T, Plaut J, Sperry J, West A, Williams DG, Yepez EA (2008) Mechanisms of plant survival and mortality during drought: why do some plants survive while others succumb to drought? New Phytol 178:719-739. https://doi.org/10.1111/j. 1469-8137.2008.02436.x

Mensah S, Veldtman R, Assogbadjo AE, Glèlè Kakaï R, Seifert T (2016) Tree species diversity promotes aboveground carbon storage through functional diversity and functional dominance. Ecol Evol 6(20):7546-7557

Mette T, Falk W, Uhl E, Biber P, Pretzsch H (2015) Increment allocation along the stem axis of dominant and suppressed trees in reaction to drought-results from 123 stem analyses of Norway spruce, scots pine and European beech. Austrian J For Sci 132:185-254

Poorter L, van der Sande MT, Thompson J, Arets EJMM, Alarcón A, ÁlvarezSánchez J, Ascarrunz N, Balvanera P, Barajas-Guzmán G, Boit A, Bongers F, Carvalho FA, Casanoves F, Cornejo-Tenorio G, Costa FRC, de Castilho CV, Duivenvoorden JF, Dutrieux LP, Enquist BJ, Fernández-Méndez F, Finegan B, Gormley LHL, Healey JR, Hoosbeek MR, Ibarra-Manríquez G, Junqueira AB, Levis C, Licona JC, Lisboa LS, Magnusson WE, Martínez-Ramos M, Martínez-Yrizar A, Martorano LG, Maskell LC, Mazzei L, Meave JA, Mora F, Muñoz R, Nytch C, Pansonato MP, Parr TW, Paz H, Pérez-García EA, Rentería LY, Rodríquez-Velazquez J, Rozendaal DMA, Ruschel AR, Sakschewski B, Salgado-Negret B, Schietti J, Simões M, Sinclair FL, Souza PF, Souza FC, Stropp J, ter Steege H, Swenson NG, Thonicke K, Toledo M, Uriarte M, van der Hout P, Walker P, Zamora N, Peña-Claros M (2015) Diversity enhances carbon storage in tropical forests. Glob Ecol Biogeogr 24(11):1314-1328

Pretzsch H (2005) Stand density and growth of Norway spruce (Picea abies (L.) Karst.) and European beech (Fagus sylvatica L.): evidence from long-term experimental plots. Eur J Forest Res 124(3):193-205. https://doi.org/10. 1007/s10342-005-0068-4 
Pretzsch H (2009) Forest dynamics, growth and yield: from measurement to model, 2010th edn. Springer, Berlin, p 664

Pretzsch H (2010) Zur Verteilung des Zuwachses zwischen den Bäumen eines Bestandes und Abhängigkeit des Verteilungsschlüssels von den Standortbedingungen. Allg Forst Jagdztg 181:4-13

Pretzsch H, Bauerle T, Häberle KH, Matyssek R, Schütze G, Rötzer T (2016) Tree diameter growth after root trenching in a mature mixed stand of Norway spruce (Picea abies [L.] Karst) and European beech (Fagus sylvatica [L.]). Trees 30(5):1761-1773

Pretzsch H, Biber P (2010) Size-symmetric versus size-asymmetric competition and growth partitioning among trees in forest stands along an ecological gradient in Central Europe. Can J For Res 40:370-384. https://doi.org/10. 1139/X09-195

Pretzsch H, Biber P, Durský J (2002) The single tree-based stand simulator SILVA: construction, application and evaluation. Forest Ecol Manag 162:3-21. https://doi.org/10.1016/S0378-1127(02)00047-6

Pretzsch H, Biber P, Schütze G, Uhl E, Rötzer T (2014) Forest stand growth dynamics in Central Europe have accelerated since 1870. Nat Commun. https://doi.org/10.1038/ncomms5967

Pretzsch H, Dieler J, Matyssek R, Wipfler P (2010) Tree and stand growth of mature Norway spruce and European beech under long-term ozone fumigation. Environ Pollut 158(4):1061-1070

Pretzsch H, Dieler J, Rötzer T (2012) Principles of growth partitioning between trees in forest stands under stress. Growth and Defence in Plants. Springer, Heidelberg, pp 311-329

Pretzsch H, Forrester DI, Bauhus J (2017) Mixed-species forests. Ecology and Management. Springer, Berlin, p 653

Pretzsch H, Kahn M, Grote R (1998) Die Fichten-Buchen-Mischbestände des Sonderforschungsbereiches "Wachstum oder Parasitenabwehr?" im Kranzberger Forst. Forstwiss Cent 117:241-257

Pretzsch H, Rötzer T, Matyssek R, Grams TEE, Häberle KH, Pritsch K, Kerner R, Munch JC (2014) Mixed Norway spruce (Picea abies [L.] Karst) and European beech (Fagus sylvatica [L.]) stands under drought: from reaction pattern to mechanism. Trees 28:1305-1321

Pretzsch H, Schütze G, Uhl E (2013) Resistance of European tree species to drought stress in mixed versus pure forests: evidence of stress release by inter-specific facilitation. Plant Biol 15:483-495

Pretzsch H, Zenner EK (2017) Toward managing mixed-species stands: from parametrization to prescription. Forest Ecosyst 4:19

Prodan M (1965) Holzmesslehre. J.D. Sauerländer's Verlag, Frankfurt am Main

Quan C, Han S, Utescher T, Utescher T, Zhang C, Liu YS (2013) Validation of temperature-precipitation based aridity index: Paleoclimatic implications. Palaeogeogr Palaeocl 386:86-95

R Core Team (2016) R: A language and environment for statistical computing. R Foundation for Statistical computing, Vienna, https://www.R-project.org/

Rais A, van de Kuilen J-WG, Pretzsch H (2014) Growth reaction patterns of tree height, diameter, and volume of Douglas-fir (Pseudotsuga menziesii [Mirb.] Franco) under acute drought stress in southern Germany. Eur J Forest Res 133:1043-1056. https://doi.org/10.1007/s10342-014-0821-7

Rigling A, Bräker O, Schneiter G, Schweingruber F (2002) Intra-annual tree-ring parameters indicating differences in drought stress of Pinus sylvestris forests within the Erico-pinion in the Valais (Switzerland). Plant Ecol 163:105-121

Rötzer T, Seifert T, Gayler S, Priesack E, Pretzsch H (2012) Effects of stress and Defence allocation on tree growth: simulation results at the individual and stand level. Growth and Defence in Plants. Springer, Berlin, Heidelberg, pp 401-432

Schober R (1975) Ertragstafeln wichtiger Baumarten. J.D. Sauerländer's Verlag, Frankfurt am Main

Schwinning S, Weiner J (1998) Mechanisms determining the degree of size asymmetry in competition among plants. Oecologia 113:447-455

Seifert T, Müller-Starck G (2009) Impacts of fructification on biomass production and correlated genetic effects in Norway spruce (Picea abies [L.] Karst.) Eur J Forest Res 128(2):155

Seifert T, Seifert S, Seydack A, Durrheim G, von Gadow K (2014) Competition effects in an afrotemperate forest. Forest Ecosyst 1(1):13

Sohn JA, Gebhardt T, Ammer C, Bauhus J, Häberle K-H, Matyssek R, Grams TEE (2013) Mitigation of drought by thinning: short-term and long-term effects on growth and physiological performance of Norway spruce (Picea abies) Forest Ecol Manag 308:188-197. https://doi.org/10.1016/j.foreco.2013.07.048

Trouvé R, Bontemps J-D, Seynave I, Collet C, Lebourgeois F (2015) Stand density, tree social status and water stress influence allocation in height and diameter growth of Quercus petraea (Liebl.) Tree Physiol 35:1035-1046. https://doi.org/10.1093/treephys/tpv067

Utschig H, Neufanger M, Zanker T (2011) Das 100-Baum-Konzept als Einstieg für Durchforstungsregeln in Mischbeständen. Allg Forstz Für Waldwirtsch Umweltvorsorge AFZ Wald AFZ 21:4-6

Wellhausen K, Heym M, Pretzsch H (2017) Mischbestände aus Kiefer (Pinus sylvestris L.) und Fichte (Picea abies (KARST.) L.): Ökologie, Ertrag und waldbauliche Behandlung. Allg Forst Jagdztg 188:3-34

Wermelinger B (2004) Ecology and management of the spruce bark beetle Ips typographus - a review of recent research. Forest Ecol Manag 202(1-3):67-82

Wichmann L (2001) Annual variations in competition symmetry in even-aged Sitka spruce. Ann Bot-London 88:145-151

Wullschleger SD, Meinzer FC, Vertessy RA (1998) A review of whole-plant water use studies in tree. Tree Physiol 18:499-512

Zang C, Hartl-Meier C, Dittmar C, Rothe A, Menzel A (2014) Patterns of drought tolerance in major European temperate forest trees: climatic drivers and levels of variability. Glob Chang Biol 20(2):3767-3779. https://doi.org/10.1111/ gcb.12637

Zang C, Pretzsch H, Rothe A (2012) Size-dependent responses to summer drought in scots pine, Norway spruce and common oak. Trees 26:557-569. https://doi.org/10.1007/s00468-011-0617-z

Zeller L, Liang J, Pretzsch H (2018) Tree species richness enhances stand productivity while stand structure can have opposite effects, based on forest inventory data from Germany and the United States of America. Forest Ecosyst 5:4

\section{Submit your manuscript to a SpringerOpen ${ }^{\circ}$ journal and benefit from:}

- Convenient online submission

- Rigorous peer review

- Open access: articles freely available online

- High visibility within the field

- Retaining the copyright to your article

Submit your next manuscript at springeropen.com 